Portland State University

PDXScholar

$1-21-2022$

\title{
The Impact of New Light Rail Service on Employment Growth in Portland, Oregon
}

\author{
Lahar Santra \\ Portland State University
}

Follow this and additional works at: https://pdxscholar.library.pdx.edu/open_access_etds

Part of the Transportation Engineering Commons, and the Urban Studies and Planning Commons Let us know how access to this document benefits you.

\section{Recommended Citation}

Santra, Lahar, "The Impact of New Light Rail Service on Employment Growth in Portland, Oregon" (2022). Dissertations and Theses. Paper 5890.

https://doi.org/10.15760/etd.7761

This Thesis is brought to you for free and open access. It has been accepted for inclusion in Dissertations and Theses by an authorized administrator of PDXScholar. Please contact us if we can make this document more accessible: pdxscholar@pdx.edu. 
The Impact of New Light Rail Service on Employment Growth in Portland, Oregon

\author{
by \\ Lahar Santra
}

A thesis submitted in partial fulfillment of the requirements for the degree of

Master of Urban Studies

Thesis Committee:

Aaron Golub, Chair

Liming Wang

Jennifer Dill

Portland State University

2021 


\begin{abstract}
This study quantitatively examines the impact of the new Light Rail Transit (LRT) service on employment growth in retail, knowledge, and service sectors before and after opening the LRT. At the corridor level, this study conducts a case study of Greenline in Southeast Portland, Oregon. The results of the corridor level study suggest that the new LRT service increased employment along the Greenline corridor among all the three sectors of interestretail, knowledge, service in the long-term (ten years) while having slightly different results for the short-term (five years), likely due to the slow growth of LRT benefits. This study also looks at the employment growth in transit-oriented development (TOD)s - Clackamas Town Center and Lents Town Center in Southeast Portland along the LRT. Clackamas Town Center transit station results suggest that new LRT service has contributed to employment growth in the short-term more than long-term.

In contrast, Lent's Town Center station analysis shows that there has been no impact or negative impact of LRT on employment change around the transit station. The individual TOD analysis helps us understand how different neighborhood characteristics like pedestrian environment, land-use patterns, location of the stations along the route contribute to employment growth in the region. Hence, providing insightful suggestions for the policymakers for making investments in LRTs.
\end{abstract}




\section{ACKNOWLEDGEMENTS}

I am grateful to many people for their support and encouragement that made my graduate school journey wonderful.

I was fortunate to have the guidance of all my committee members. My thesis advisor Prof. Aaron Golub has given me a lot of freedom in navigating through this journey besides providing enormous support and guidance for my research work. His work on public transportation and equity has continued to inspire me. His courses on Public Transportation, Transportation Policy, and Planning have helped me shape my research interests in public transit and social equity. I would like to express my gratitude towards Prof. Liming Wang. I have been lucky to take Professor Liming's courses on travel demand modeling, transportation, and land use. He has been very approachable and helped me pay attention to minute details in my research. He has always offered invaluable feedback that helped me steer through all the technical and fundamental challenges in my work. I would like to thank Prof. Dill for her immense patience to listen to my innumerable thesis-related questions and challenges. Her insightful comments have helped me write my thesis more coherently. She personifies all the qualities that I would like to emulate in the future as a researcher.

My journey here would not have been the same without the support of my fellow Ph.D. students at the Toulan School of Urban Studies and Planning. Special thanks to Sarah Carnaroli, Sara Urbina, Nicholas Puczkowskyj, Huijun Tan, Maryam Amiri for allowing 
me to rant incessantly. All of you have been extremely supportive, be it in person or virtually from any corner of the world.

Finally, this thesis is dedicated to my beloved family. I would like to thank my parents, Mrs. Kakali Santra and Dr. Santosh Santra, and my elder sister, Mrs. Titir Santra, for believing in me and always encouraging me to work towards my goals. Thanks to my partner, Rushabh Shah, for unceasingly believing in me and sticking with me through all the good times, and bad. I am eternally grateful and indebted to all my family for their limitless support. 


\section{Contents}

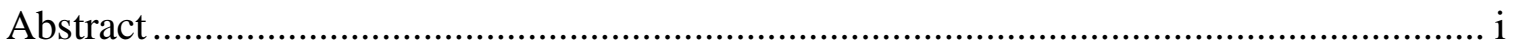

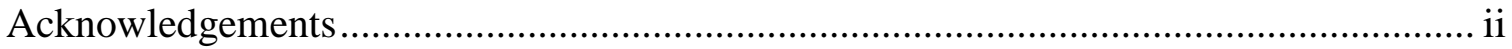

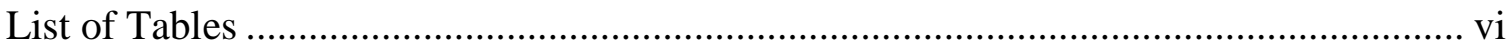

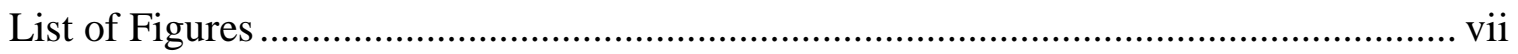

1 Transit-Oriented Economic Development: The Impact Of The Light Rail On Employment Growth In Portland, Oregon ...............................................................

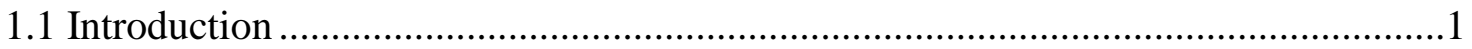

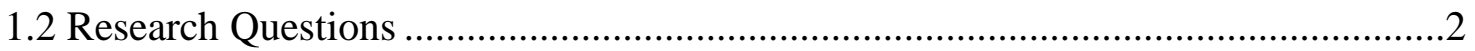

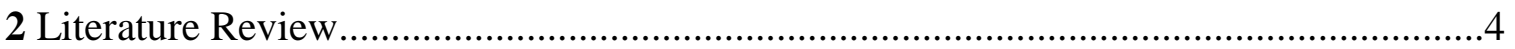

2.1 Economic Effects Of Transportation Systems Investment .....................................4

2.2 Accessibility As A Measure Of Transportation System Performance ......................8

2.3 Framework For Agglomeration Benefits From Transportation System ...................9

2.4 Relationship Between Accessibility Benefits Of Specific Transportation Modes And Agglomeration Benefits ..................................................................................11

3 Effects Of Light Rail Service On Employment Growth In The Knowledge, Retail, And Service Sector At The Corridor Level, South-East Portland ........................................14

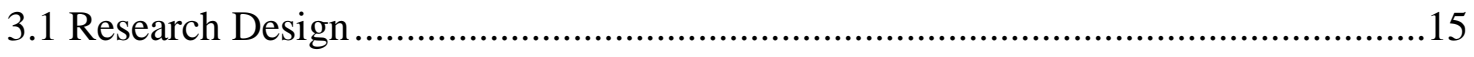

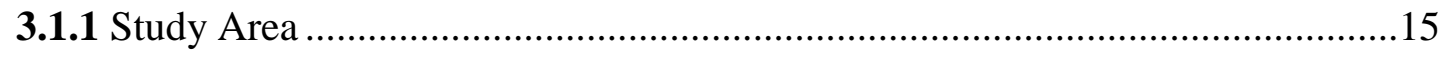

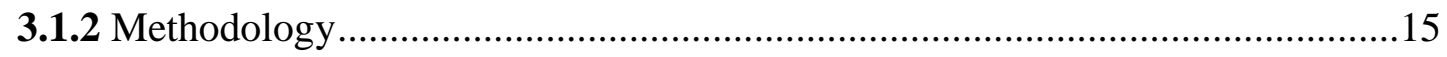

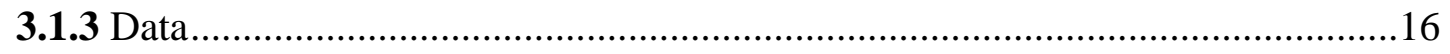

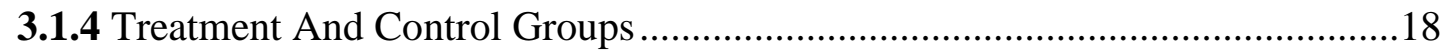

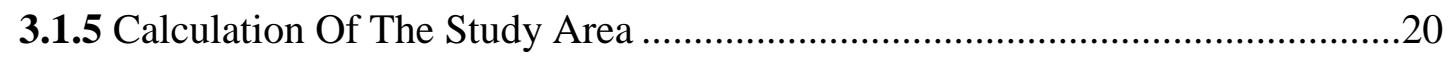

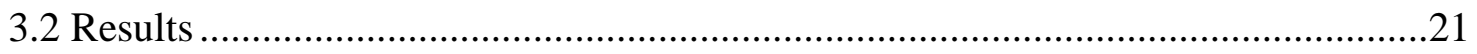

3.2.1 First Control Group- Half-Mile From Blueline Stops ...................................22

3.2.2 Second Control Group- Half-Mile To One-Mile From Greenline Stops ..........25

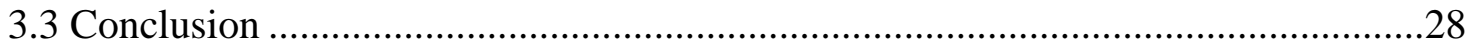

4 Effect Of A New Light Rail Service On Employment Growth In Clackamas Regional

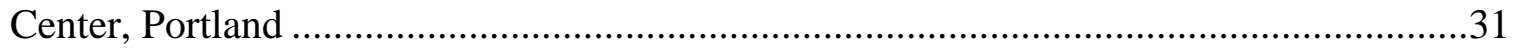

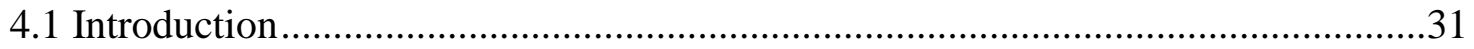

4.1.1 Transit-Oriented Development in Southeast Portland ...................................31 
4.2 Clackamas Regional Center

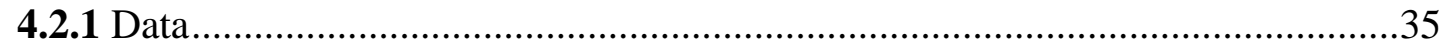

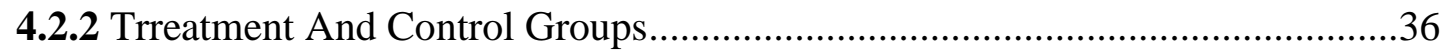

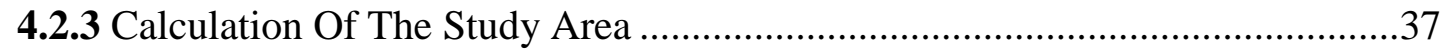

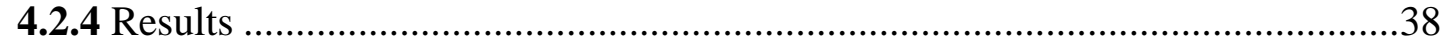

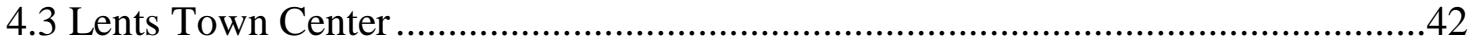

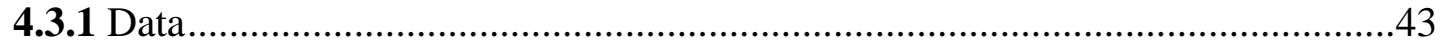

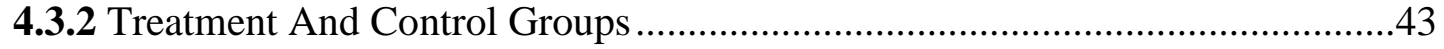

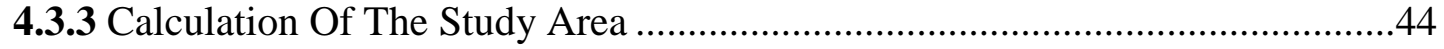

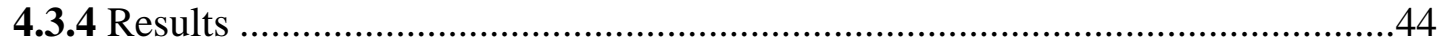

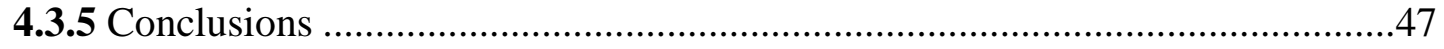

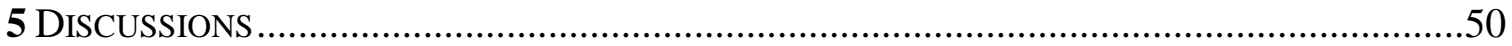

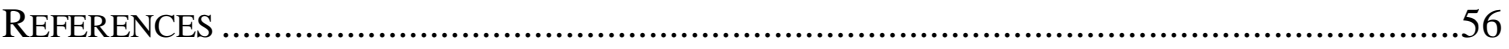




\section{LIST OF TABLES}

Table 1- Difference in Difference to estimate the effect of the Greenline LRT on Job growth between 2008- 2013....................................................................................... 21

Table 2- Difference in Difference to estimate the effect of the Greenline LRT on Job

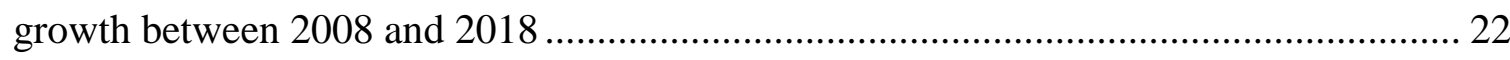

Table 3-Difference in Difference to estimate the effect of the Greenline LRT on Job

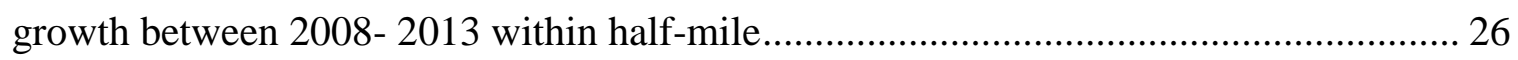

Table 4- Difference in Difference to estimate the effect of the Greenline LRT on Job growth between 2008- 2018 within half-mile.......................................................... 26

Table 5- Difference in Difference estimation of light rail service on Clackamas Regional

Center between 2008 and 2013 ........................................................................... 37

Table 6-Difference in Difference estimation of light rail service on Clackamas Regional

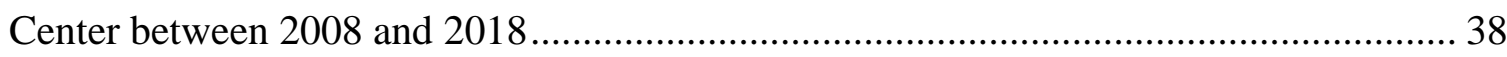

Table 7-Difference in Difference estimation of light rail service on Lents Town Center between 2008 and 2013

Table 8-Difference in Difference estimation of light rail service on Lents Town Center between 2008 and 2018

Table 9-Glimpse of all the case studies explaining the impact of LRT on employment (upward arrow implies increase, downward arrow implies decrease) ............................. 50 


\section{LIST OF FIGURES}

Figure 1--Routes and stations of the Max Light Service in Portland, Oregon ................ 16 Figure 2-Half-a mile buffer area around the Green Max stops (Treatment) and Blue Max

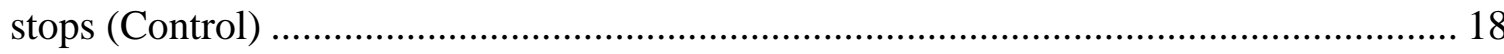

Figure 3- Half a mile to one mile around the Green Max stops .................................... 19 Figure 4- The causal effect of Greenline LRT on service sector jobs between 2008-2018

Figure 5-The causal effect of Greenline LRT on knowledge sector jobs between 20082018.

Figure 6- The causal effect of Greenline LRT on retail sector jobs between 2008-2018. 25 Figure 7-The causal effect of Greenline LRT on retail jobs between 2008-2018 within half-mile. 27

Figure 8-The causal effect of Greenline LRT on knowledge sector jobs between 20082018 within half-mile

Figure 9- The causal effect of Greenline LRT on service sector jobs between 2008-2018

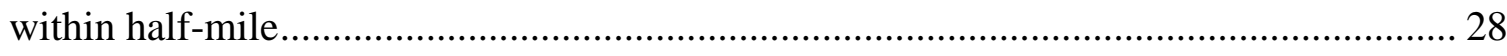

Figure 10-Study Area Clackamas Town Center Transit Center .................................... 36 Figure 11- Showing the impact of light rail service on total jobs around the Clackamas 39 Figure 12-Showing the impact of light rail service on retail jobs around the Clackamas 39 Figure 13- Showing the impact of light rail service on service sector employment around the Clackamas Transit Center ................................................................................. 40 Figure 14-Showing impact of light rail service on knowledge sector jobs around the

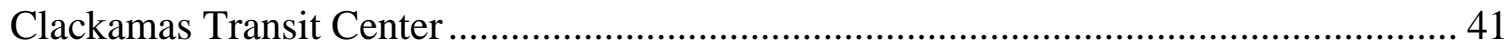

Figure 15-Study Area around Lents/Se Foster Rd Transit Center ................................. 44 Figure 16-Showing impact of light rail service on retail sector jobs around the Lents Town Center. 45

Figure 17-Showing impact of light rail service on service sector jobs around the Lents Town Center. 46 Figure 18-Showing impact of light rail service on knowledge sector jobs around the Lents Town Center. 46 


\section{TRANSIT-ORIENTED ECONOMIC DEVELOPMENT: THE IMPACT OF THE LIGHT RAIL ON EMPLOYMENT GROWTH IN PORTLAND, OREGON}

\subsection{INTRODUCTION}

Over the last three decades, billions of tax dollars have been spent constructing 650 miles of light rail lines in approximately 16 regions in the United States $(Y, 2014)$. While these investments were to induce more people to change their mode of commuting from driving to sharing - and to provide the urban poor with easy access to quality life and job opportunities - these investment projects are also advocated as economic development tools to facilitate infill development and contribute to overall development around the areas adjacent to transit corridors. Given the high cost of transportation infrastructure, it is important to understand the impact of these expenditures on economic growth. Although research (Lund et al., 2004)(Golub et al., 2012) has been conducted on the influence of rail transit on the property values near the stations, there is limited understanding of the impact of the transit investments on employment growth. Understanding the impact of transit stations on station area property values is essential in measuring the economic impact, but it explains only a fraction of the complexities present in the big picture. Understanding impacts on employment growth are important because it contributes to regional economic growth (Frenken et al., 2007).

This study aims to provide an in-depth understanding of the effect of the new light rail transit (LRT) on employment growth in different sectors such as knowledge, service, and retail. This study will estimate the effect of new LRT service on employment growth, 
both in the corridor and in adjacent neighborhood (Transit-oriented neighborhood), explaining the changes over a period of five years and ten years. While this study analyses change over a short time frame, we expect the results are still significant in explaining the interactions between transit accessibility and employment.

\subsection{RESEARCH QUESTIONS}

This paper answers the following research questions:

1) What impact does the opening of a new light rail service have on employment growth in its adjacent retail, service, and knowledge industries compared with changes in business activities in neighborhoods without a new light rail service?

2) How does employment in the adjacent retail, service, and knowledge industries change over time after new light rail service starts?

3) How does the LRT's impact on new businesses vary as distance from the stations increases?

To answer these questions, this paper employs a difference-in difference approach to provide a quasi-experimental explanation of LRT's impact on employment growth in Portland, Oregon, from 2008 to 2013 and from 2008 to 2018.

The first research question investigates the effects of the new LRT service on change in employment in the Knowledge, Service, and Retail sectors both at the corridor and the adjacent neighborhoods. Transit accessibility is expected to improve regional access to labor markets(Credit, 2018). Transit can also foster knowledge spillovers; 
information exchange is an important driver of innovation in the knowledge economy. In addition, higher visibility through locations near new transit stations will most likely benefit customer-oriented firms like retail, service providers, and hospitality businesses. Overall, public transit facilitates the visibility of the surrounding business increases demand and provides access to a larger market area, resulting in increased employment in the sectors that are influenced by transit accessibility.

The second research question investigates whether the immediate benefits of the LRT wear off with time. Perception can often be more significant than the real benefits when it comes to the economic development of any fixed-route transit system If the LRT system provides these mobility benefits, the accessibility benefits may be observed immediately at the opening of the LRT and the benefits may diminish over time after the system stabilizes that may explain the 'novelty factor' of a new transportation infrastructure(Mohammad et al., 2013).

The third research question helps understand how effective the transit-oriented development (TODs) can be by investigating the change in employment growth in the Knowledge, Service, and Retail industry based on their proximity to the transit stops. The spatially related employment growth information is also helpful for the station-area planners and businesses who would capitalize on the economic benefits of the new transit system. We anticipate more development-supportive infrastructure (for example, higher density) close to the stations. 


\section{Literature Review}

\subsection{ECONOMIC EFFECTS OF TRANSPORTATION SYSTEMS INVESTMENT}

One of the most frequently discussed issues in transport is whether infrastructure investment promotes economic growth at regional and local levels. When we talk about additional transport benefits that transport infrastructure investment produces, we do not just refer to a reduction in travel time. There are other potential benefits from investments in terms of economic development.

We can agree that places which already have a well-developed, well-connected transport infrastructure network may not respond as strongly to investments in access. Moreover, transport infrastructure acts as a complement to existing conditions to boost economic development. Transport infrastructure investment in this context adds a supporting character along with other existing conditions (that we will discuss later) to promote economic development (Ozbay et al., 2003). What are the considerations for transportation investment decisions? Berechman (Banister \& J, 2000) explains that there are three essential conditions required for any such transport infrastructure to promote economic development. The first is the presence of other underlying economic growth attributes like skilled labor, agglomeration, labor market economies and other dynamics in the local economy. The second important condition is related to the scale of the investment, its location, and the timing of the investment. We could say that the transportation infrastructure investment decisions are not made in isolation. So, one needs to consider the spatial factors and the 'place' in the network. For regional growth to occur, we must ensure 
improvements at the network level and not just at a single point. The third type of condition is related to political factors that refer to a broader policy environment within which the transport investment decisions are made. Other contributing factors here are the level of investment (local, region, or federal), institutional policies, and other necessary complementary policy actions. Accounting for all these factors is necessary for any additional transit investments to yield economic benefits (Banister \& J, 2000).

Studies have shown that transport infrastructure changes are related to economic development(Meija, 2012)(Banister \& J, 2000). Meija-Dorantes (2012) shows that the distance from subway stations affects certain firm location choices. On the other hand, Padeiro (Padeiro 2013) concludes that the presence of stations does not affect job growth, although the presence of a highway can become a prominent predictor. Ozbay(Ozbay et al., 2003) investigated the relationship between accessibility and economic development and concluded that accessibility changes are related to changes in employment growth. Although these studies mainly explain a positive relationship between transportation investment and local economic development, several other empirical studies show almost no effect on local economic growth. In his study, Eagle(Stephanedes \& Eagle, 1986)explained that there was no overall relationship between highway expenditures and changes in employment levels.

Von Thunen (1826) and Alonso's $(1960,1964)$ classic bid-rent theory provides the conceptual framework for research on the economic effects of transportation systems, 
which led to the empirical work analyzing the impact of transportation investments on property values and employment(Credit, 2019).

Transportation plays a vital role in the bid-rent theory that attempts to explain various economic activities' distribution and spatial patterns based on purely economic considerations. According to Thunen's (1826) theory of the agricultural land use allocation, transportation cost for various goods determines the concentric distribution of land use allocation, which allows heavier and bulky products to be grown closer to the market while lighter weight products or those that require a large area for growing (ex: wheat) will be located farther from the market(Beckmann, 1968).

Back in the 1960s, Alonso (1960, 1964), Muth (1968), and Mills (1967) explained the concept of urban land uses for the residents who would require shorter commutes. Lowincome households with a minimal transportation budget, for example, would pay more for rent to be located closest to the city center. On the other hand, households whose preferences are usually more space and more isolation (suburban households) prefer being located farther from the center. The spatial distribution of land use is defined by a gradient of property values that are affected by the accessibility to the center (transportation networks).

Few of the studies focused on how highway investments increase regional property values, thus indicating a regional increase in land value with the increase in highway accessibility (Adkins, 1959)(Giuliano G, 2004). While some research shows a positive impact of highway accessibility on the property, employment and business-clustering, 
some studies show adverse effects or insignificant effects of highway accessibility (Duranton \& Turner, 2012)(Seo et al., 2014)(P, 2000). As highway networks become more built out, the incremental increase in accessibility from each highway project decreases. Proximity to the highway can be associated with traffic noise and pollution, affecting residential property values (Nelson, 1982).

Research related to the economic impact of the public transit system started in the 1970s and 1980s with studies on how station proximity increases property values (Cervero, R., Radisch, 1996) if the service itself is reliable, and is built in areas with an already high economic growth and development potential (Cervero, 1984) (Golub et al., 2012) (Landis et al., 1994) (Chatman et al., 2016). Other researchers have suggested that the economic benefits that appear to be due to transit systems could instead be due to the spillover effect from the other regions of development. Transit generally affects the property value due to benefits arising from adjacent areas (Mohammad et al., 2013). Credit (2018), Holl (2004), Meija (2012) have concluded that there is a positive impact of transportation investments on business agglomeration.

These studies discuss the local agglomeration impacts of transportation systems on business productivity regarding the total amount of economic activity accessible within a certain travel radius (Melo et al., 2017). Other studies associate transportation systems' agglomeration benefits at a city or a regional scale (Andersson et al., 2016)(Gerritse \& Arribas-Bel, 2018). Most agglomeration literature has shown that agglomeration benefits 
are nominal, and more attention needs to be given to these processes (Andersson et al., 2016).

\subsection{ACCESSIBILITY AS A MEASURE OF TRANSPORTATION SYSTEM PERFORMANCE}

The concept of accessibility has been known to measure the quality of interaction between land development patterns of a given area and the transportation system (Cascetta, 2009). We are aware that accessibility is interdisciplinary and has been studied in many fields like urban geography, network, spatial economics, and regional science. There is a difference between place-based and people-based measures of accessibility. Place-based is usually measured by calculating the number of activities and destinations available from a specific origin within a particular time and distance constraint. These measures capture the accessibility of different geographical areas that do not differentiate between individual variations inaccessibility. Accessibility measures have been used in a variety of applications for an intervention involving transportation and land-use systems. These measures help understand and model transportation/land-use interactions help understand and model travel demand, and assess the effectiveness of transportation plans and projects (Carteni, 2014).

Hansen (1959) defines accessibility as the opportunity that an individual possesses at a given location to participate in a particular activity or set of activities. Hence, it is seen as a measure of the net utility received by an individual in a given location. Alternatively, it could be phrased as the consumer surplus that individuals achieve from using the 
transport and land-use systems (Leonardi, 1978). Alternatively, we could define it as measuring an average number of opportunities that the residents possess to participate in a particular activity (Wach \& Kumagai, 2015) with a specific period at a certain distance.

\subsection{FRAMEWORK FOR AGGLOMERATION BENEFITS FROM TRANSPORTATION SYSTEM}

Much of the literature on the relationship between the economic effects of transportation systems focuses on the property value effect rather than business agglomeration as the economic output (Golub et al., 2012) (Seo et al., 2014).

The direct impact of a transportation investment can be seen in terms of accessibility for the adjacent land parcels. The scale of accessibility measures depends on many other factors other than just the existence of transit services. For example, a welldesigned pedestrian environment would help contribute to the full potential for accessibility benefits. Other factors also influence the scale of the agglomeration benefits, such as the specific site, distance to the central business district, zoning, and the nature of the business. Additionally, different modes of transportation provide unique features that are more likely conducive to some agglomeration benefits, and some businesses have different responses (Credit, 2018).

The other point of consideration is how the specific agglomeration benefits are advanced through the accessibility benefits. Six agglomeration benefits are consumer market access, social networks, freight access, labor market access, information, and spillover benefits (P, 2000) (Chatman, D.G.\& Noland, 2011). 
Better accessibility derived from transportation investments can help with the visibility of certain businesses like the retail and service sectors. These businesses require access to the customers, which is also facilitated by the better connection of the businesses to the entire urban market (Credit, 2019). Transportation accessibility also promotes social networks and the maintenance of 'weak ties' by reducing the cost of face-to-face communication (Credit, 2019) (Giuliano et al., 2010). The social connection is important among the producers, suppliers, customers for creating new businesses and for the potential entrepreneurial environment (Spigel, 2015). In addition, the social network is also valued for encouraging a culture conducive to competition and cooperation, thus leading to better regional competitiveness (Porter, 2000).

One of the other prominent accessibility benefits is an increase in information availability (Marshall, 1890). The businesses benefit from more access to knowledge of the new business opportunities and facilitating informal interactions, leading to an overall increase in innovation and entrepreneurship. These agglomerative benefits that impact entrepreneurship are essential for a sustainable regional economy (Credit, 2018).

The agglomeration factors can be understood both as internal and external factors to the firm. Although property value is a prominent external indicator of improved accessibility, there are other external benefits of agglomeration, like the growth of new businesses and spillover agglomeration. A new transit station would not only contribute to the agglomerative benefits of the businesses located adjacent to the transit line, but it would 
also add to the secondary benefits of the nearby neighborhoods by developing complementary businesses along with the transit station-related business activities.

Also, there are indirect economic benefits from transportation investments that may not be related to accessibility. For example, Fischer (Fischer, 2018) identified the important contribution of public transit infrastructure in explaining to the entrepreneurs that the local government would be investing in specific neighborhoods to create businesses, and promote development, all of which would result in an overall increase in property values.

\subsection{RELATIONSHIP BETWEEN ACCESSIBILITY BENEFITS OF SPECIFIC TRANSPORTATION MODES AND AGGLOMERATION BENEFITS}

It is important to understand whether existing ridesharing services like Uber/Lyft or the shared autonomous vehicle networks promote similar agglomeration benefits as the traditional transit, micro-transit modes, and SOVs. The consumer market benefits are most likely to be created by the rapid transit modes because they tend to spread on a regional scale, rather than a neighborhood scale (WC, 2003).

The businesses that benefit from these economies are customer-oriented firms like retailers, services, and entertainment. A well-planned automobile and transit infrastructure investment can benefit these businesses. Other important requirements for manufacturing, wholesale, or large-scale retail are freight access and labor market access. Labor market access is helpful for businesses without specialized hiring needs like manufacturing, wholesale, retail, and entertainment industries (Credit, 2018). Specific industries require 
specialized or higher human capital, need a more targeted search for employees and may be less dependent on transportation access for a large pool of candidates (WC, 2003).

Social networks are facilitated through interpersonal interaction both at a regional level and locally. The businesses that gain from face-to-face communication space are the ones that require much in-person interaction such as education institutions or high-tech businesses (Appendix A). All passenger modes increase the interpersonal accessibility and potential for building more social networks to a certain extent. Saxenian (Saxenian, 1994) explained how knowledge spillovers occurred among Silicon Valley firms at the local bars. Passenger transportation modes encourage such agglomeration mechanisms.

Earlier studies (Van Soest, D. P., Gerking, S., \& Van Oort, 2006)have claimed that slow transportation modes encourage informal interaction, casual socialization, and personal experiences of situations. This is usual to happen over relatively shorter distances. High-tech, advanced services, and knowledge industries tend to benefit from these agglomeration mechanisms.

Previous studies have showed a positive impact on highway accessibility on the property, employment, and business-clustering. Similarly, some studies have explained direct positive impact of transportation investments on business agglomeration(Holl, 2004)(Meija, 2012). Ozbay(2003) investigated the relationship between accessibility and economic development and concluded that accessibility changes are related to changes in employment growth. Credit (2018) has explored how the transit accessibility benefits have advanced agglomeration benefits like consumer market access, social networks, freight 
access, labor market access, and information flow by examining the creation of new businesses before and after opening of LRT. This study will explore similar questions using the case of light rail service in Portland, Oregon, examining the impact of light rail accessibility on agglomeration benefits by understanding the employment growth before and after opening the light rail service. Instead of focusing on the creation of new businesses along the transit corridor, this study focusses on the change in employment among the existing businesses in Southeast Portland over ten years. It will also take a closer look at the employment growth in transit-oriented development (TOD)s - Clackamas Town Center and Lents Town Center in Southeast Portland along the LRT. 
3 EFFECTS OF LIGHT RAIL SERVICE ON EMPLOYMENT GROWTH IN THE KNOWLEDGE, RETAIL, AND SERVICE SECTOR AT THE CORRIDOR LEVEL, SOUTH-EAST PORTLAND

The research questions that are being discussed in this chapter are:

1) What impact does the opening of a new light rail service have on employment growth in its adjacent retail, service, and knowledge industries compared with changes in business activities in neighborhoods without a new light rail service?

2) How does employment in the adjacent retail, service, and knowledge industries change over time after new light rail service starts?

3) How does the LRT's impact on new businesses vary as distance from the stations increases?

Employment accessibility research emerged from the 'spatial mismatch hypothesis. The focus of the study was on the concentration of high unemployment rates among the urban black men in inner-city neighborhoods in cities such as Chicago and Detroit. These studies(Adkins, 1959) explained how the confluence of employment decentralization, residential segregation, and lack of transportation opportunities, caused a disconnect between the work locations and housing. This often contributed to the concentration of unemployment. One of the debates focuses on whether the spatial mismatch was a result of 'space' or 'race', or whether these were the result of distance-to-work locations or just people's racial identity(Trimet, 2010)(Boschmann, 2011). 
The relationship between employment and accessibility is bidirectional. On the one hand, transit plays a vital role in business location decisions. On the other hand, employment locations are still significant in transit planning. At least $59 \%$ of the transit ridership in the U.S is known to be for employment-related trips(Tilahun \& Fan, 2014). Existing evidence also shows that employment density and the proximity to mass transit are as important as the residential density for increasing transit ridership and achieving transportation and land-use goals(Seo et al., 2014) (Chatman et al., 2016)(Kuby et al., 2004). A well-connected transit network would allow the working class to benefit from the clustering and agglomeration of businesses(Tomer,A. Kneebone, E. Puentes,E. 2011).

\subsection{RESEARCH DESIGN}

\subsubsection{STUDY AREA}

This study chooses the Green Line and Blue Line in the Portland metropolitan area as the case studies. Figure 1 shows the routes and stations of the MAX light rail system. The Green Line is a 15-mile LRT line that opened in September 2009. It extends the transit service to the east side of the Portland metropolitan area by connecting Clackamas, Happy Valley, and downtown Portland. The Blue Line connects Hillsboro, Beaverton, Portland City Center, East Portland, and Gresham.

\subsubsection{Methodology}

This study aims to quantify the effects of a new LRT service on employment growth at the corridor level and neighborhood level in East Portland, Oregon. This study uses a 
quasi-experimental design by specifically using the difference-in-difference (DID) method to estimate the group-level fixed effects of treatment.

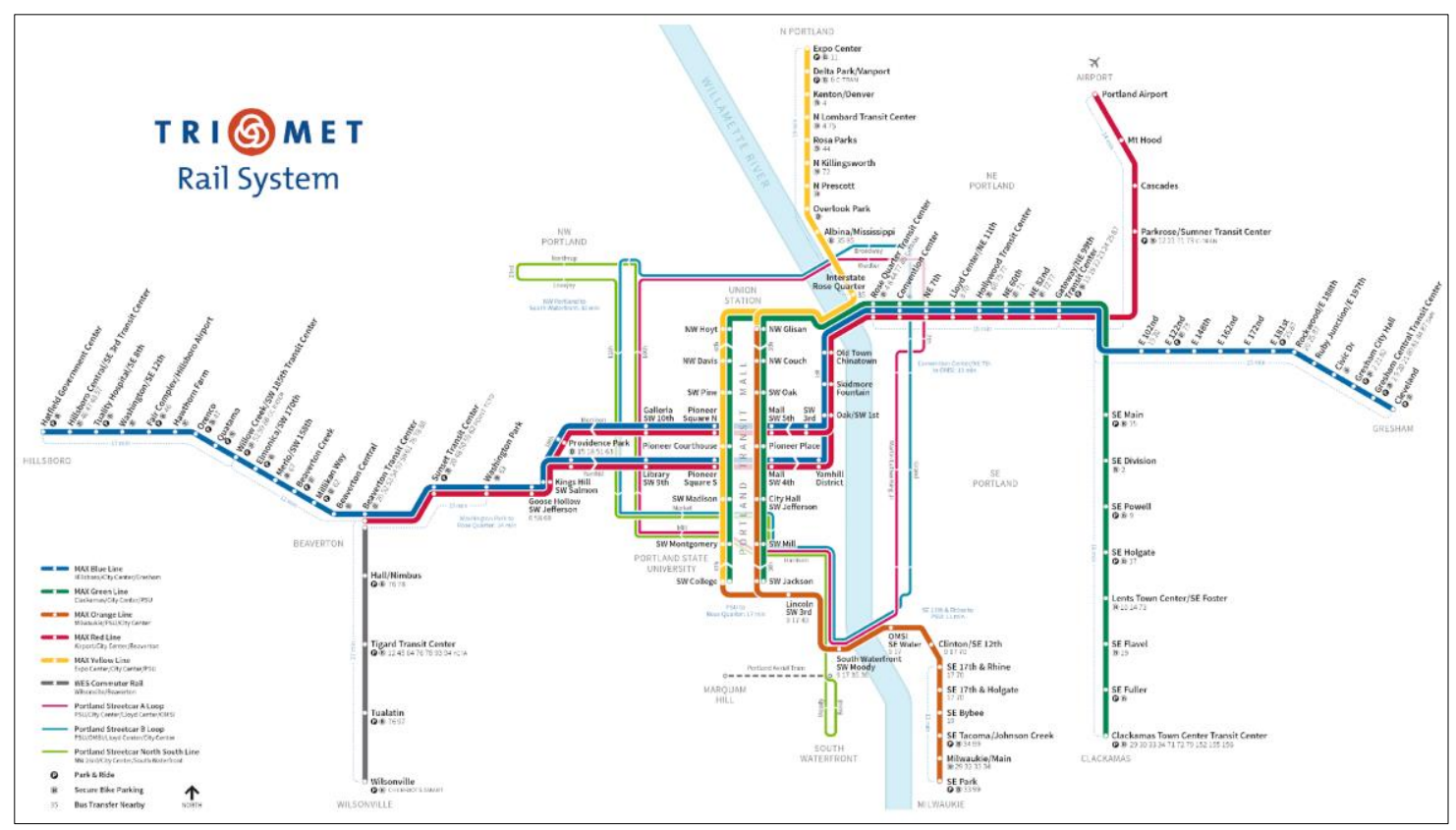

Figure 1--Routes AND STATIONS OF THE MAX Light SERVICE IN PORTLAND, OREGON

\subsubsection{DATA}

I have used the Workplace Area Characteristic (WAC) data from the Longitudinal Employment Household Dynamics (LEHD) for this study. The variables of interest (WACLEHD) for this study are a total number of jobs in a) Retail Businesses- NAICS 44-45; b) Knowledge Sector - NAICS 51 (Information), NAICS 52 (Finance and Insurance), NAICS 54 (Professional, Scientific and Technical Service), NAICS 55 (Management of Companies and Enterprises); 
c) Service Sector- NAICS 72(Accommodation and Food Services), NAICS 81 (Other Services).

Retail businesses include stores selling retail goods, including everything from groceries and office supplies, to cars and household goods. Knowledge businesses include software publisher firms in the information sector; professional, scientific services include lawyers' offices and management consulting firms. Services include hotels, restaurants, bars, and other personal services, such as dry cleaning or shoe repair.

For the light rail treatment area, buffers of half a mile and a half to one mile (10- and 20minute walks, respectively) were created using the US Census 2008, 2013, and 2018 block shapefiles (United States Census Bureau, 2008, 2013, 2018).

To understand a longitudinal economic impact of the light rail for five years (20082013) and ten years (2008-2018), this study uses a difference-in-difference approach to compare the change in the given variables (growth of jobs in specific industries at census blocks between a selected treatment area and a control area, before and after the intervention of light rail services). In this study, the intervention point is 2009 , when the Green Max line opened. 


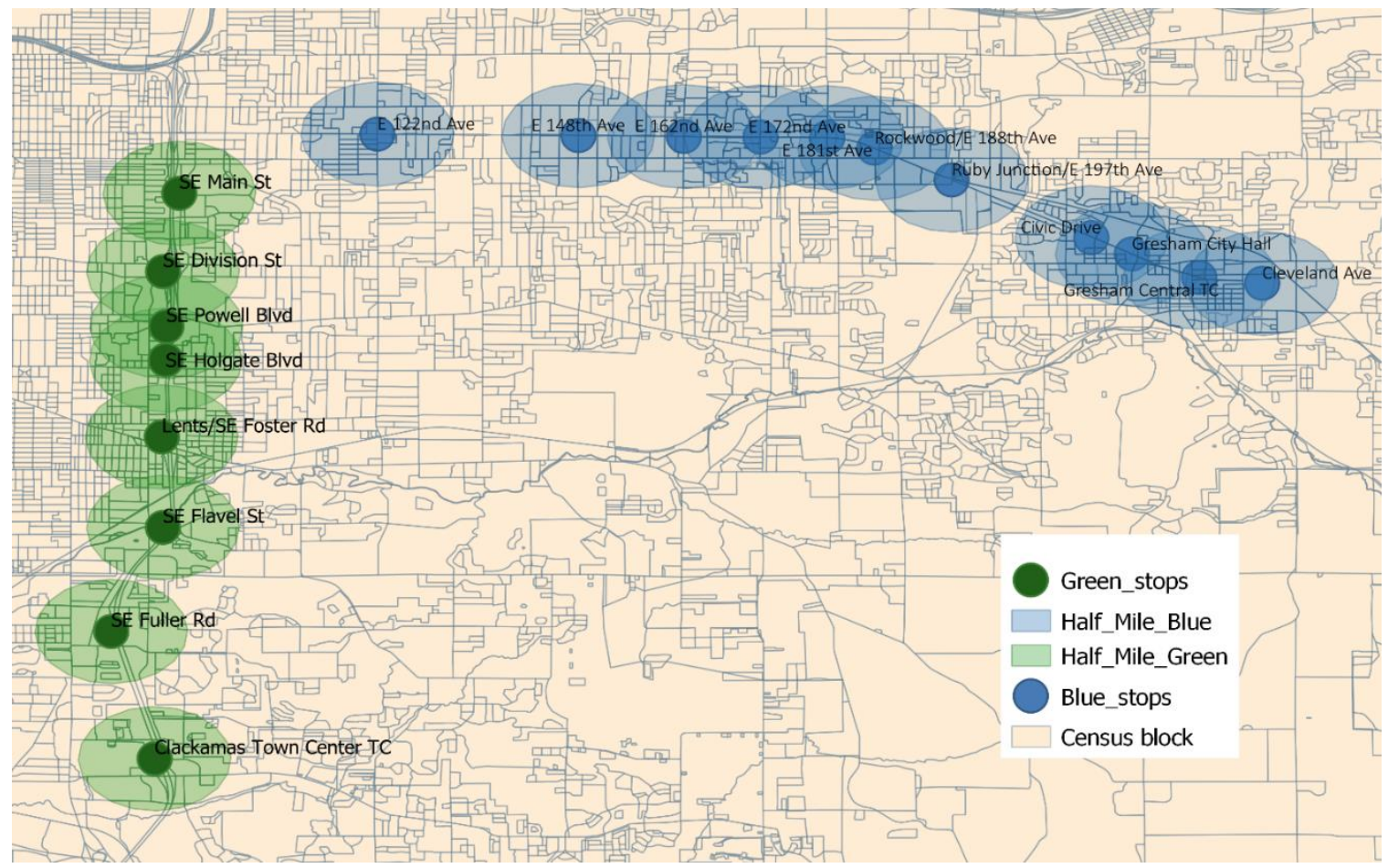

Figure 2-HALF-A MILE BUfFER AREA AROUND THE GREEN MAX STOPS (TREATMENT) AND BLUE MAX STOPS (CONTROL)

\subsubsection{TREATMENT AND CONTROL GROUPS}

This study tries to find the combination of the most similar pre-intervention pattern of both the treatment and control groups. For the treatment area, buffers were calculated at a census block level for half a mile and half to one mile around each Greenline transit station (Figure 2) to form the treatment group for workers in specific industries (Retail, Knowledge, Services) at these calculated buffer distances. The buffer distance of half a mile has been known as the common area of impact around the transit stations (Mohammad et al., 2013)(Zhao et al., 2003). The selected Green Line stations for the study are SE Main, SE Division, SE Powell, SE Holgate, Lents Town Center/ SE Foster, SE Flavel, SE Fuller, Clackamas Town Center Transit Center. 
There are two control groups in this study. One is defined by the workers in the retail, employment, and service sector within a half-mile buffer area around the selected Blue Max transit stations (Figure 2). The selected Blue Line stations for the study are E $148^{\text {th }}, E 162^{\text {nd }}, E 172^{\text {nd }}, E 181^{\text {st }}$, Rockwood, Ruby Junction, Civic Dr, Gresham City Hall, Gresham Central Transit Center, Cleveland. The second control group comprises retail, knowledge, and service workers within a half to one-mile buffer calculated around the selected Green Line Max stops (Figure 3).

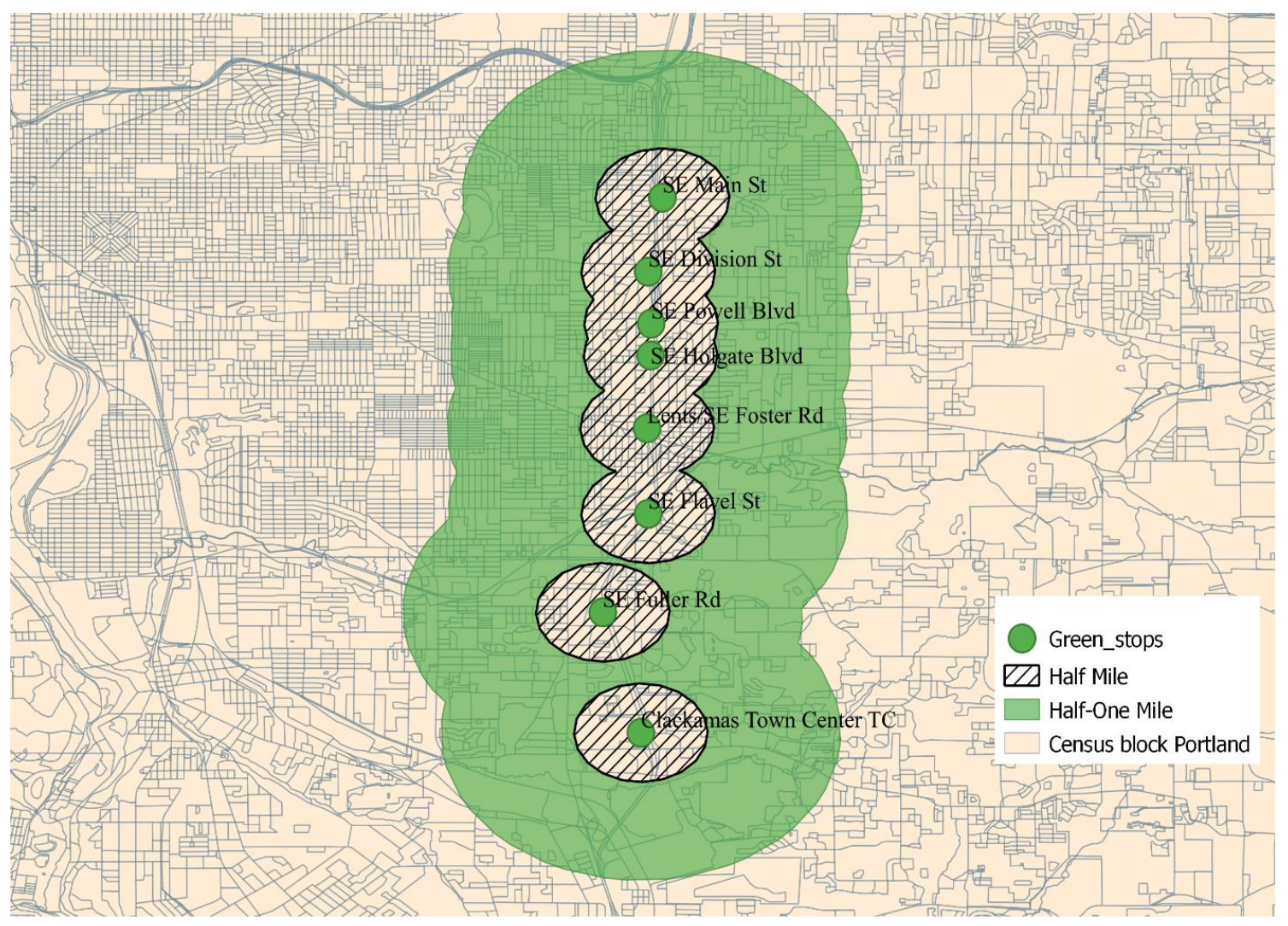

FIGURE 3- HALF A MILE TO ONE MILE AROUND THE GREEN MAX STOPS 
In a quasi-experimental study like this, it is important to choose treatment and control groups in a way that had had a similar pattern before the intervention occurred. This is required to reduce any selection bias and strongly claim that the differences (if any) between the treatment and control groups occurred due to the intervention and not due to any other pre-existing differences between these groups.

Blue Max line opened in 1986 to Gresham (East of Portland), Oregon. This segment (figure 2) was chosen to ensure the control group has no new light rail service intervention. Since this study looks at the change that occurred around the Green line (Treatment group) and Blueline (Control group) between 2008 and 2013, it is improbable that the blue line would still experience some effects of light rail development that opened up in 1986. Additionally, both the groups are light area adjacent areas, which would ensure similar land uses within the half-a-mile buffer from the stations.

\subsubsection{CALCULATION OF THE STUDY AREA}

The study area (figure 2) has been calculated by using half a mile buffer around the selected green line (toward Clackamas) stops and selected blue line stops (toward Gresham). GIS tools were used to calculate the amount of land from each block that falls within each station's half-mile buffer treatment area and control areas. The census variables for each block have been weighted by the land share by dividing the total census block area and multiplying by the fraction of census block area that falls in the study area. The total jobs for the block have been divided by the total block area and then multiplied by the fraction of block area that lies within the buffer area (total jobs/square mile). To further 
normalize (there is a considerable difference of the employment numbers among the census blocks within the buffer of the same stations), I have divided the aggregate of the variables (total, retail, knowledge, service sector jobs) by the total buffer area (5.91 square miles for half a mile buffer \& 8.42 square miles for one-mile buffer).

To take care of the intersected buffer area between the stations (figure 2), I have dissolved the intersected station area. Since this study is at an aggregate scale and not an individual station area, removing any duplicated census block would cover the elimination of the intersected station buffer area.

\subsection{RESULTS}

TABLE 1- DifFERENCE IN DIFFERENCE TO ESTIMATE THE EFFECT OF THE GREENLINE LRT ON JOB GROWTH BETWEEN 2008- 2013

\begin{tabular}{|c|c|c|c|c|c|c|c|}
\hline & & & $\begin{array}{r}\text { Dif } \\
\text { Differen } \\
\text { fo }\end{array}$ & $\begin{array}{l}\text { ence in } \\
\text { Estimati } \\
\text { years }\end{array}$ & & & \\
\hline & Pre- & Post- & Pre- & Post- & Treatment & Control & \\
\hline Variables & Treatment & Treatment & Control & Control & Difference & Difference & Diff_in_Diff \\
\hline Total Jobs & 1187 & 3290 & 1630 & 3426 & 2102 & 1795 & 306 \\
\hline Retail & 310 & 971 & 322 & 697 & 660 & 375 & 284 \\
\hline Knowledge & 64 & 225 & 128 & 300 & 160 & 170 & -10 \\
\hline Services & 257 & 629 & 322 & 758 & 372 & 435 & -63 \\
\hline
\end{tabular}


TABLE 2- DiFFERENCE IN DIFFERENCE TO ESTIMATE THE EFFECT OF THE GREENLINE LRT ON JOB GROWTH BETWEEN 2008 AND 2018

\begin{tabular}{|l|l|l|l|l|l|l|l|}
\hline \multicolumn{7}{|c|}{$\begin{array}{l}\text { Difference in Difference } \\
\text { Estimation for 10 years }\end{array}$} \\
\hline & Pre- & $\begin{array}{l}\text { Post- } \\
\text { Variables }\end{array}$ & Pre- & Post- & Treatment & Control & \\
Treatment & Treatment & Control & Control & Difference & Difference & Diff_in_Diff \\
\hline Total Jobs & 1187 & 8941 & 1630 & 5235 & 7753 & 3605 & 4147 \\
\hline Retail & 310 & 2042 & 322 & 1044 & 1731 & 722 & 1009 \\
\hline Knowledge & 64 & 465. & 128 & 321 & 401 & 192 & 209 \\
\hline Services & 257 & 1625 & 322 & 1224 & 1368 & 902 & 465 \\
\hline
\end{tabular}

\subsubsection{FIRST CONTROL GROUP- HALF-MILE FROM BLUELINE STOPS}

The five-year data (table 1) suggests that there has been an increase of about 306 total jobs per square mile in the half-mile treatment area compared to the half-mile control area between 2008 and 2013. There is an increase of about 284 jobs, a decline of 10 jobs, 63 jobs in the retail, knowledge, and service sectors, respectively (per square mile) within the half-mile Greenline area compared within the half-mile distance from the Blueline Max stops. Retail accounts for more than $90 \%$ of the increase in total employment around the green line adjacent area. Figures 4,5,6 show the difference-in-difference plots to explain the causal effect of the green line service on the number of jobs in the service, knowledge, and retail sectors for five years and ten years.

The ten years data (table 2) indicates that of the total job increase in a half-mile buffer around the Green Max stops, the retail industry contributes to about $24 \%$ increase in the total jobs growth, and the knowledge industry contributes to about $5 \%$ of the total job 
growth. In comparison, the service sector contributes to about $11 \%$ of the total job growth between 2008 and 2018 due to opening of the new Greenline service. There has been an increase of about 1000 jobs in the retail sector, 210 jobs in the knowledge sector, and 465 jobs in the service between 2008 and 2018. The pattern indicates that the "novelty factor" does not wear off with time (Mohammad et al., 2013). The jobs continue to increase in all the sectors. There seem to be no immediate perceived benefits to the new light rail service; otherwise, the numbers would have plummeted within five years and then continued to decline. However, the data is not enough to conclude whether the pattern starts changing a little further down.

The increase over ten years tells us that as the system stabilizes, its agglomeration benefits continued to create more jobs over ten years than any immediate (2008-2013) increase after the opening of the Greenline. This impact has been observed in relation to the blue line station adjacent blocks (with no new intervention of light rail). Any economic benefits arise from the system's usefulness as a mode of transportation, which requires good service, low cost, and broad coverage. Otherwise, the economic benefits visible at the beginning of the service — primarily those dependent on the novelty factor-will fade over time. 


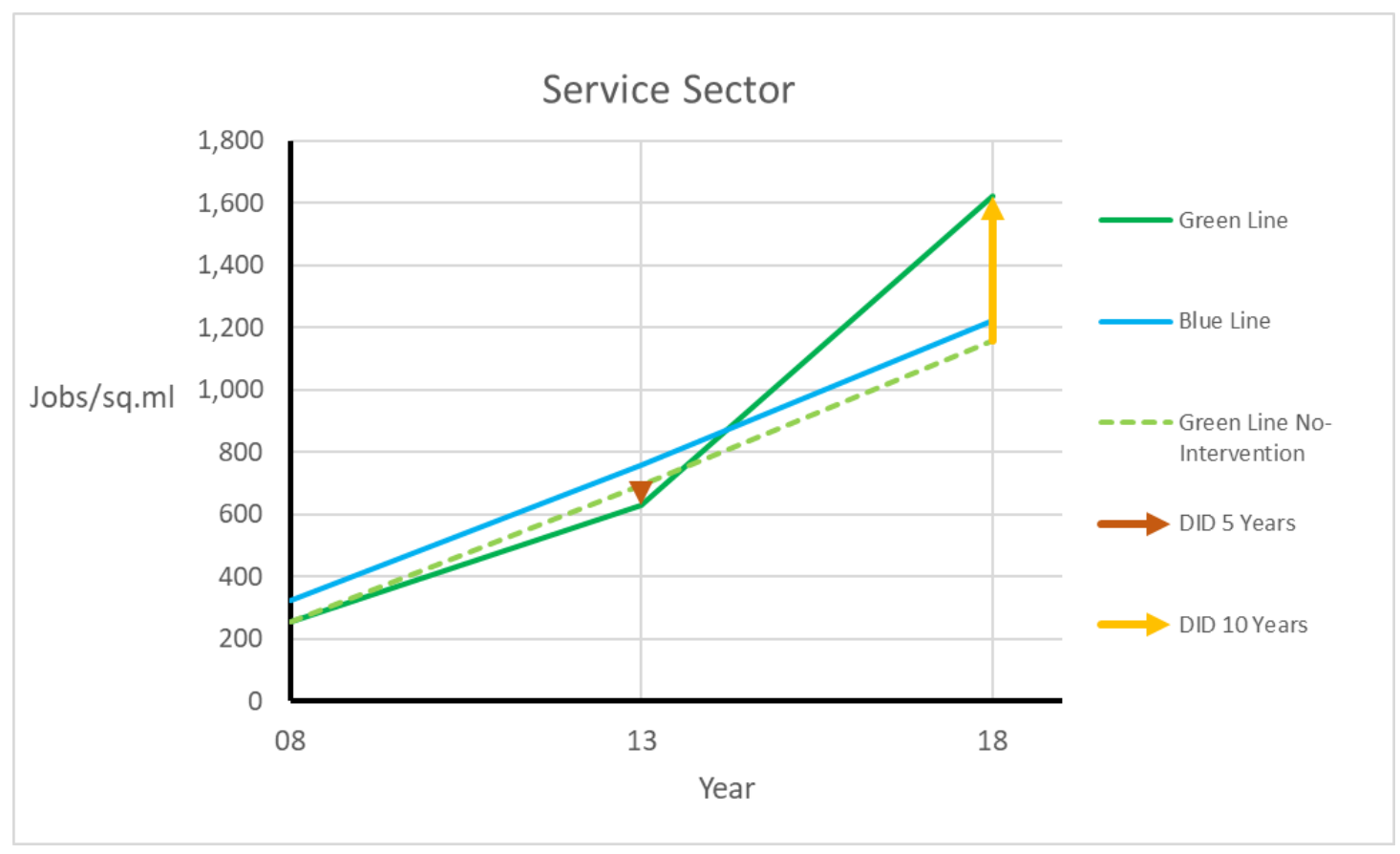

FIGURE 4- THE CAUSAL EFFECT OF GREENLINE LRT ON SERVICE SECTOR JOBS BETWEEN 2008-2018

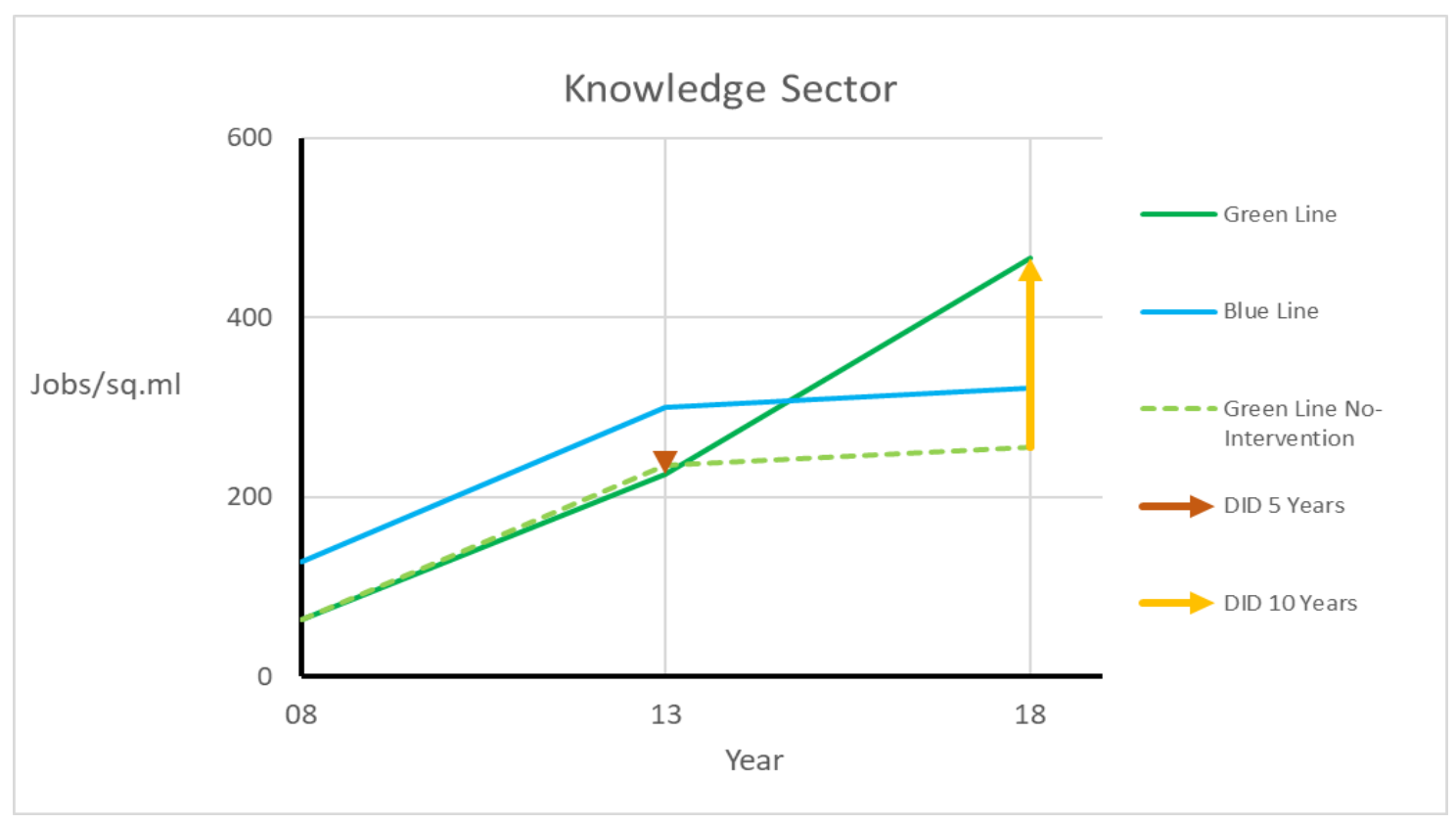

FIGURE 5-THE CAUSAL EFFECT OF GREENLINE LRT ON KNOWLEDGE SECTOR JOBS BETWEEN 2008-2018 


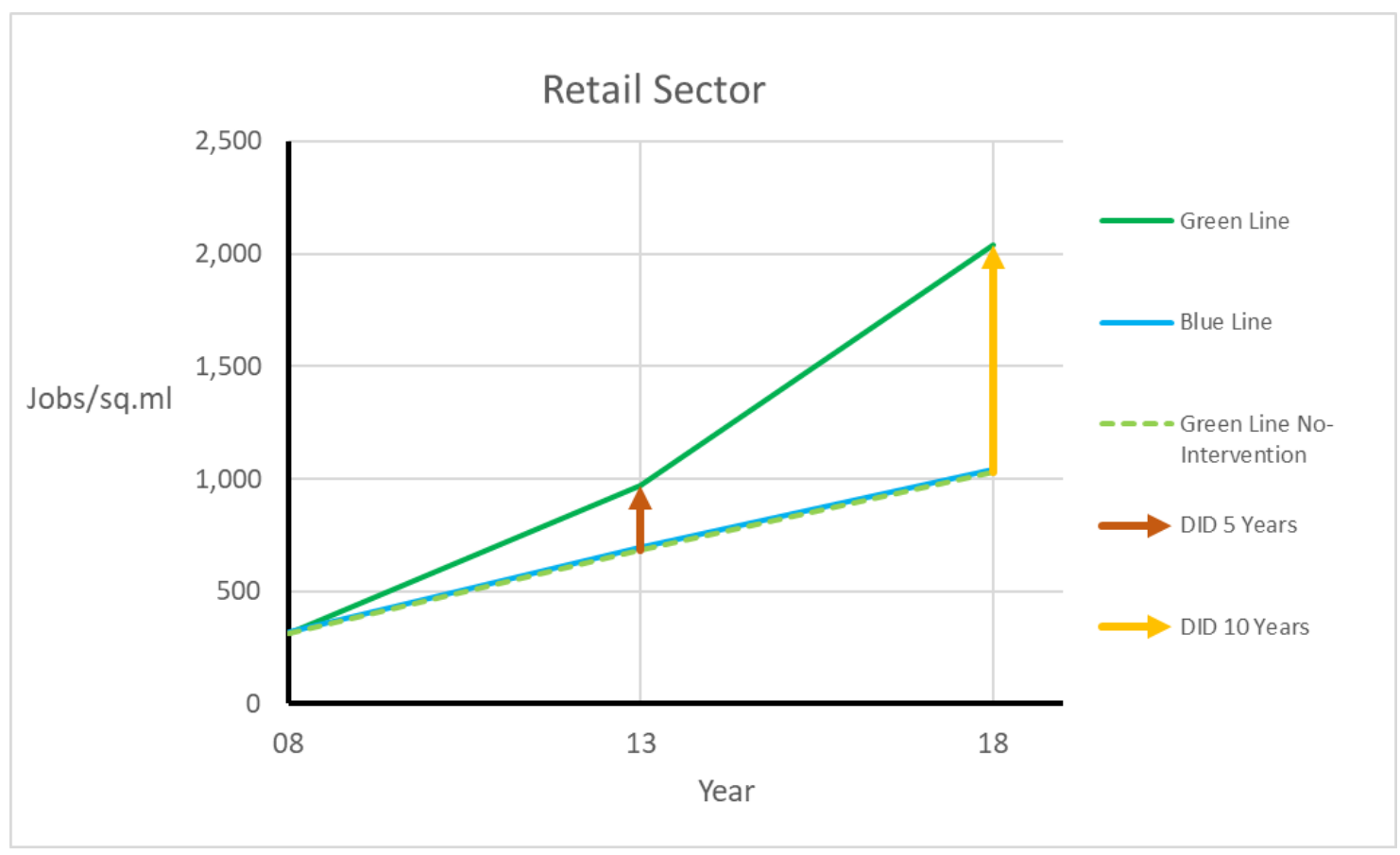

FigURE 6- THE CAUSAL EFFECT OF GREENLINE LRT ON RETAIL SECTOR JOBS BETWEEN 2008-2018

\subsubsection{SECOND CONTROL GROUP- HALF-MILE TO ONE-MILE FROM GREENLINE STOPS}

The second control group data shows that the retail industry has experienced the most significant impact among all the other sectors. Retail jobs have increased by 205 , the knowledge sector jobs by 35 , and the service sector jobs by 135 , as seen in Table 3 . The change in the number of jobs occurred over five years between 2008 and 2013. The ten years of data reveal that retail jobs within the half-mile treatment area increase by 1337 compared with the half-mile to one-mile distance from the Greenline stops. Similarly, knowledge sector jobs increase by 257 , and service sector jobs increase by 1056 , as seen in table 4. Thus, in both five- and ten-years' data results, retail industry jobs within a half- 
mile distance show the maximum impact of the new LRT service compared to the halfmile to one-mile distance.

TABLE 3-DIFFERENCE IN DIFFERENCE TO ESTIMATE THE EFFECT OF THE GREENLINE LRT ON JOB GROWTH BETWEEN 2008- 2013 WITHIN HALF-MILE

Five Year Difference in Difference Estimation for Half Mile and Half to One Mile

\begin{tabular}{|l|l|l|l|l|l|}
\hline Variables & Pre-treatment & Post-treatment & Pre-Control & Post-Control & Diff-in-Diff \\
\hline Total Jobs & 1187 & 3290 & 1199 & 2926 & 375 \\
\hline Retail & 310 & 971 & 345 & 800 & 205 \\
\hline Knowledge & 64 & 225 & 82 & 208 & 34 \\
\hline Services & 257 & 629 & 244 & 482 & 134 \\
\hline
\end{tabular}

TABLE 4- DIFFERENCE IN DIFFERENCE TO ESTIMATE THE EFFECT OF THE GREENLINE LRT ON JOB GROWTH BETWEEN 2008- 2018 WITHIN HALF-MILE

\begin{tabular}{|l|l|l|l|l|l|}
\hline \multicolumn{5}{|c|}{ Ten Year Difference in Difference Estimation for Half Mile and Half to One Mile } \\
\hline Variables & Pre-treatment & Post-treatment & Pre-Control & Post-Control & Diff-in-Diff \\
\hline Total Jobs & 1187 & 8941 & 1199 & 3764 & 5188 \\
\hline Retail & 310 & 2042 & 345 & 739 & 1337 \\
\hline Knowledge & 64 & 465 & 82 & 227 & 257 \\
\hline Services & 257 & 1625 & 244 & 555 & 1056 \\
\hline
\end{tabular}




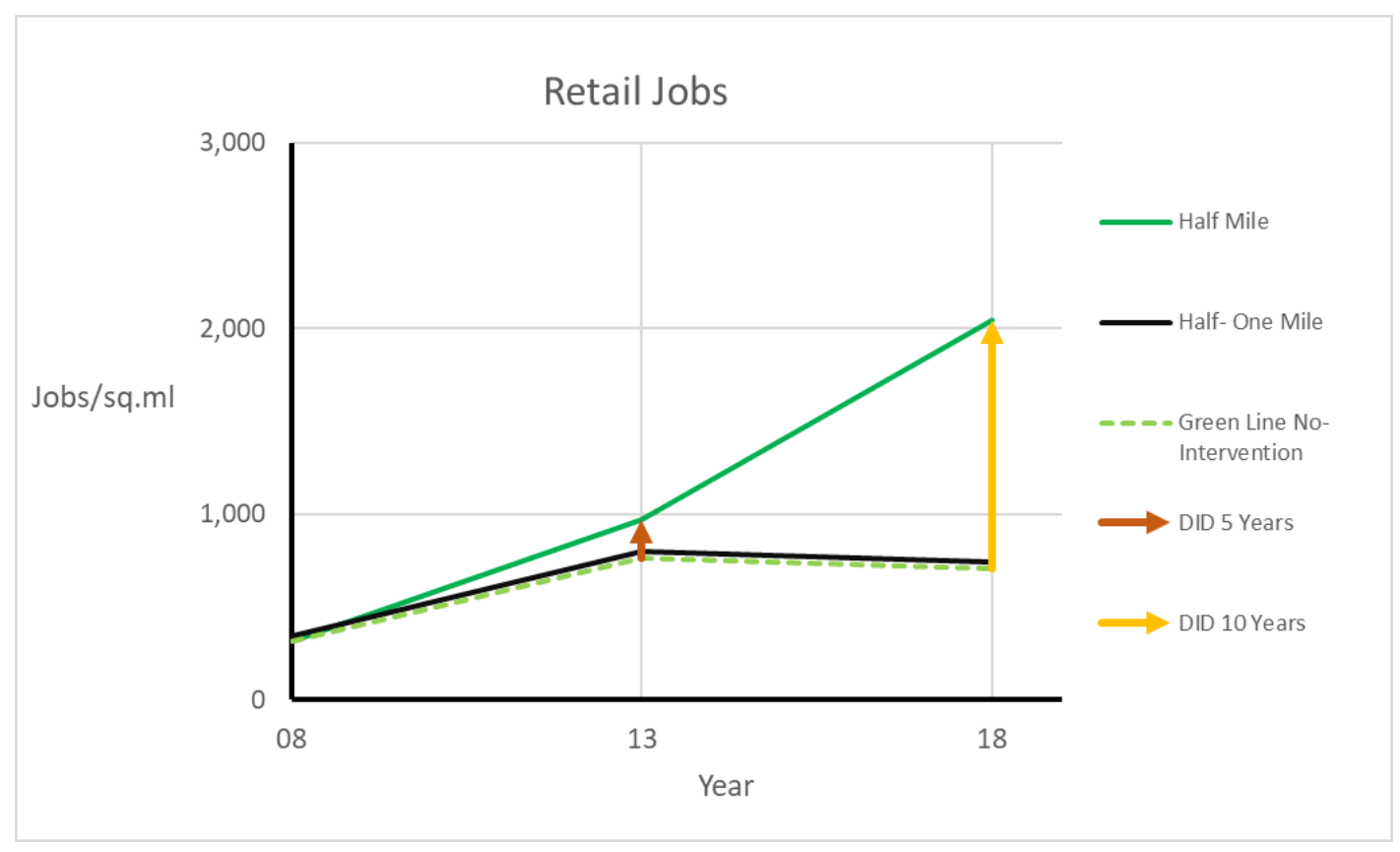

FIGURE 7-THE CAUSAL EFFECT OF GREENLINE LRT ON RETAIL JOBS BETWEEN 2008-2018 WITHIN HALF-MILE

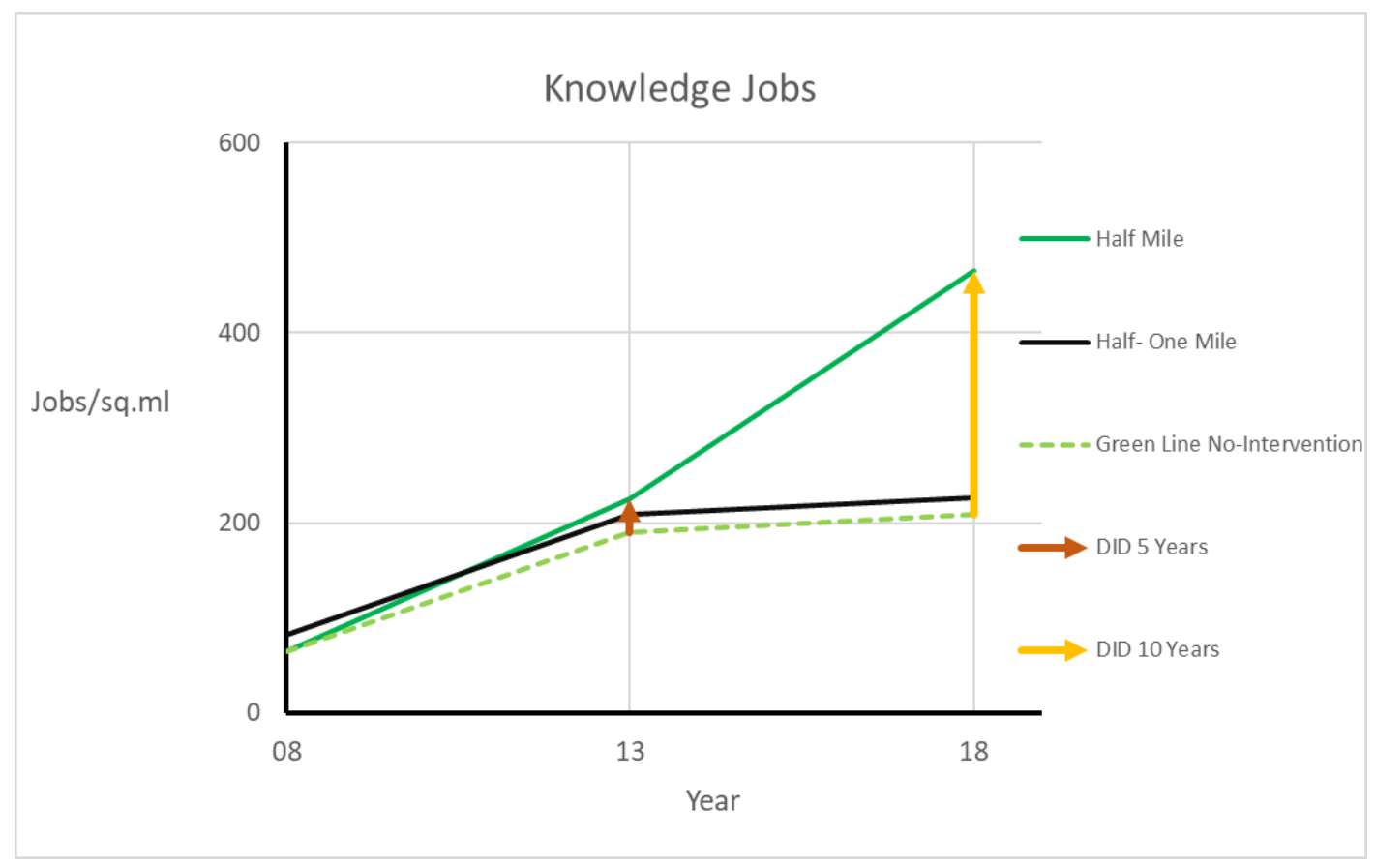

FigURE 8-THE CAUSAL EFFECT OF GREENLINE LRT ON KNOWLEDGE SECTOR JOBS BETWEEN 2008-2018 WITHIN HALF-MILE 


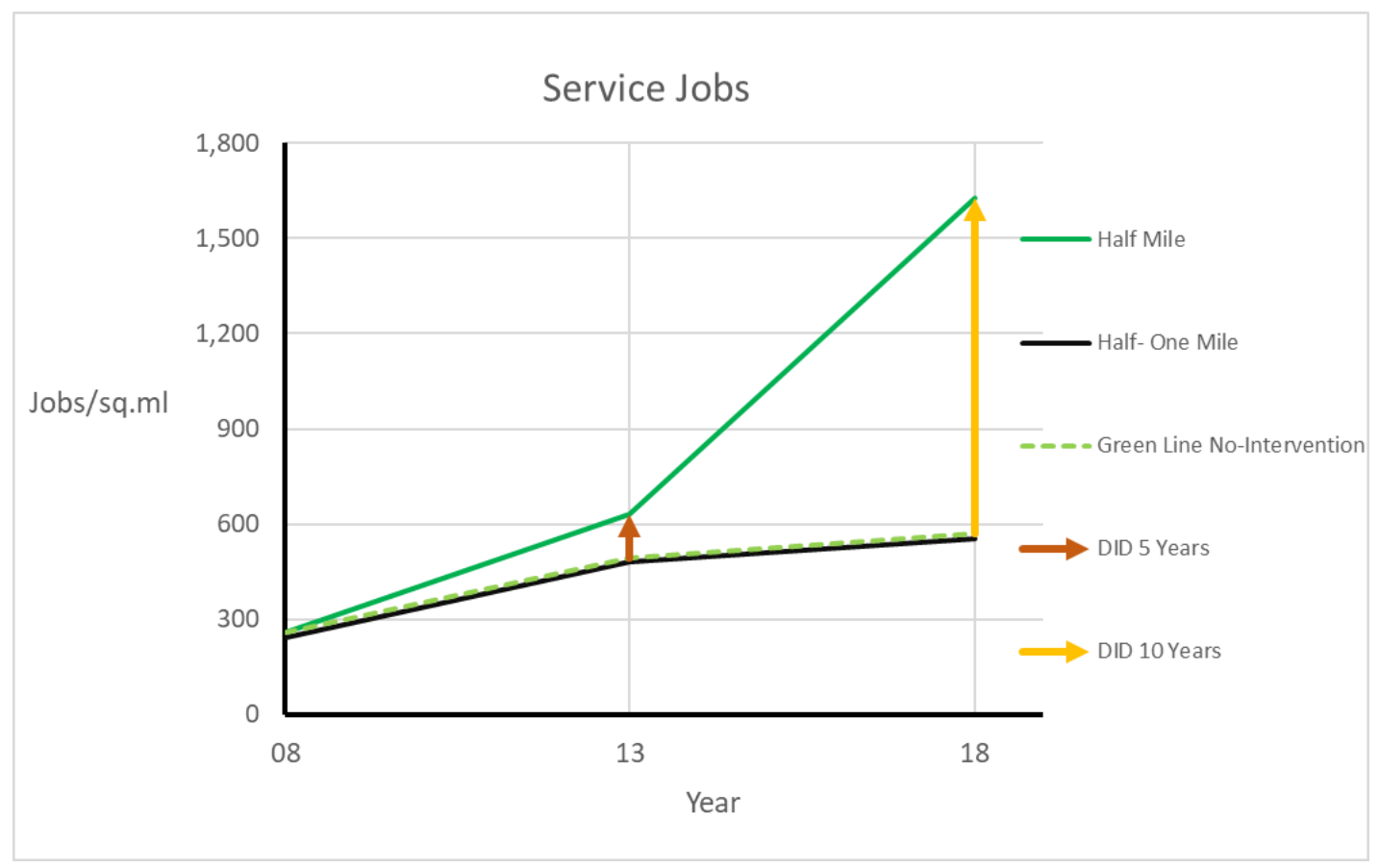

FIGURE 9- THE CAUSAL EFFECT OF GREENLINE LRT ON SERVICE SECTOR JOBS BETWEEN 2008-2018 WITHIN HALF-MILE

\subsection{CONCLUSION}

This analysis reveals three important factors regarding the planning and construction of the Greenline Max light rail service in Southeast Portland. The study's first finding is that the new Greenline LRT service has increased jobs in the retail sector compared to the increase in jobs in the Blueline control area where light rail already exists. The second key result is that the employment kept increasing significantly over ten years for both the control groups. In this case, the immediate benefits due to the opening up of the LRT continued growing over time, the agglomeration and visibility benefits continued to rise. The third key finding is that the proximity to the light rail increases employment in all three sectors of interest when compared with the half-mile to one-mile buffer from the Greenline stops. The retail industry receives the most significant impact. This suggests that 
the TOD planning was impactful and the adjacent businesses have benefitted from the LRT service.

The increase in employment in retail tells us that the Greenline facilitated regional access to the labor market. Benefits from a larger market area and overall visibility could have helped customer-oriented firms like retail. On the other hand, the decline in jobs in the service and knowledge sector compared to the Blue controlled area for five years may have been due to the increase in property value near the station area. An increase in stationarea adjacent property value may have caused a few firms to shift away from the green line adjacent neighborhoods. Firms in the information sector like software publishers, finance and insurance companies, lawyer's offices, and management consulting firms may perceive accessibility benefits from proximity to transit. TOD schemes may have been more effective for fostering employment growth in the retail sector; the closer they are to the stations, the more impactful the influence is.

The retail industry is highly compatible with the neighborhoods around the rail stations. The increased pedestrian traffic created by the transit riders should increase the retail business. Most of the planning preferences often focus on commercial development more than residential development because of the financial benefits generated by the business tax (Schuetz, 2015). Neighborhood retail services such as grocery stores, pharmacies, and restaurants provide essential amenities for the residents, such as healthful food. The rail investments could improve the quantity or quality of neighborhood retail services. The variation in the station characteristics also impacts nearby economic activity either through the different physical context and indirectly through differences in the transit 
ridership. The types of features affecting the retail growth are grouped into station physical characteristics, neighborhood physical characteristics, neighborhood economic and demographic characteristics, and neighborhood regulatory, political environment. 


\section{EFFECT OF A NEW LIGHT RAIL SERVICE ON EMPLOYMENT GROWTH IN CLACKAMAS REGIONAL CENTER, PORTLAND}

\subsection{INTRODUCTION}

This chapter involves two case study analyses- Clackamas Town Center and Lents Town Center. The microscopic view of the impact of LRT accessibility on employment in these TODs would help us understand the additional contributing factors (location of the station, land use, alternative modes of transportation, pedestrian environment, etc.) in the relationship between transit accessibility and employment growth.

The research questions being discussed in this chapter are:

1) What impact does the opening of a new light rail service have on employment growth in its adjacent retail, service, and knowledge industries compared with changes in business activities in neighborhoods without a new light rail service (in this case, it's outside half mile but within one mile buffer) ?

2) How does employment in the adjacent retail, service, and knowledge industries change over time after new light rail service starts?

\subsubsection{TRANSIT-ORIENTED DEVELOPMENT IN SOUTHEAST PORTLAND}

Metro's 2040 Growth concept identifies the regional centers, town centers, station areas, and corridors as the primary areas for growth over the next 30 years. However, some of these centers do not have existing infrastructure, urban design, or land-use patterns to encourage the transit-oriented model and reduce auto dependence. For instance, Gateway, 
one of the critical transit nodes, offers some infrastructure to support sustainable growth but lacks pedestrian infrastructure and accommodating land use. Moreover, not all the transit centers have been supported by earlier investments to ensure the transition to major growth-inducing TODs enlisted by the Portland Metro.

The Metro 2040 Growth concept lists long-range regional goals to improve livability, preserve open space, and reduce greenhouse gas emissions throughout the Portland region. To implement these values, transportation and land-use planning must integrate to preserve the urban growth boundary and concentrate growth within the designated town centers, regional centers, and station areas. Transit-oriented development is one of the critical approaches to enhance this sustainable growth concept of Metro 2040 (Transit-Oriented Development Strategic Plan / Metro TOD Program, n.d.).

One of the critical components of transit-oriented neighborhoods is having a vibrant community where the residents of TODs can reduce the auto dependence by accessing jobs, shopping, and services by bicycle, transit, or on foot. This would help with reduced transportation costs and improve public health. There are essentially two components to the 'vibrant communities' - 1) Mix of land uses: where vibrant communities include compact development and access to housing, employment, shopping in proximity 2) Walkability: vibrant communities where the residents and visitors have travel options.

The Southeast Portland and North Clackamas region is defined by the Max Greenline, Interstate 205 on the east, the max blue line, and Interstate 84 to its north. The region has a diverse pattern of development. Neighborhoods in the inner Southeast Portland neighborhoods still reflect the streetcar orientation. However, further east, the 
neighborhoods that developed in unincorporated Multnomah and Clackamas counties after 1940 have lower density and less street connectivity with a more automobile-oriented street.

Several transit-oriented developments in the Southeast and North Clackamas are served by the bus and walkable mixed-use neighborhoods. New light rail service, extensions of light rail, and streetcar services in this area promise to improve travel times, reliability, and convenience for the region with an already established transit riders base (Trimet, 2010).

The Max light rail system expanded into Southeast Portland and Clackamas County in 2009 with the opening of the Green Line. Transit riders from Clackamas County now can get to Downtown Portland or even transfer to Airport, East Portland, and Gresham (Gateway) in a one-seat ride. The 6.5-Mile Green Line extension runs between the Gateway Transit Center and Clackamas Town Center along the I-205. It connects to the existing Blue Line tracks from Gateway to downtown Portland along the I-84. At the same time, the Greenline connects two regional centers, Gateway and Clackamas, and a town center, Lents, identified by the 2040 Metro Growth Concept. The I-205 segment of the green line connects about eight new stations and five Park and Ride lots. The I-205 or the Portland Mall Light Rail Project that created the Green Line has a budget of about 575 million dollars, with Federal funding covering about $60 \%$ of the project cost.

It is believed that there will be about one million new residents in the Portland region by 2030. This corridor is expected to experience significant growth with the influx of new residents. Nearly 100,000 new jobs would be created along the corridor by 2030 , 
facilitated by employment growth at Oregon Health and Science University, Portland State University, Southeast Portland, and North Clackamas County (Trimet, 2010).

\subsection{CLACKAMAS REGIONAL CENTER}

In 1983, the completion of the northern portion of Interstate 205 included a transitway parallel to much of the highway as it passed through Multnomah County. Meanwhile, the Portland Mall opened in 1978, providing bus service with a dedicated alignment on several blocks of $5^{\text {th }}$ and $6^{\text {th }}$ avenues in downtown Portland. As a result, Clackamas County became one of the region's fastest-growing areas. The need for developing a high-capacity transit to Clackamas County and a new downtown alignment increased with time. In addition to this, the expansion of light rail was identified as a critical part of the growing transportation system as a four-rail line on the one existing downtown alignment had reached capacity, and the region's population is expected to grow by one million new residents by 2030(Trimet, 2010).

Clackamas Town Center Transit Center on the Max Greenline, identified as a Plan and Partner TOD typology, is located within the Clackamas Regional Center, regional shopping, and a key employment center. Nevertheless, the pedestrian connections are restricted due to their location near the I-205, low-street connectivity, and ample parking lots (Transit-Oriented Development Strategic Plan / Metro TOD Program, n.d.).

This chapter presents a case study of the Max Green light rail service (Clackamas Town Center Transit Center) on employment growth in the retail, knowledge, and service sectors in the Clackamas Regional Center, evaluating Clackamas transit center as a TOD. 


\subsubsection{DATA}

Like the corridor level study, the Workplace Area Characteristic (WAC) data have been used from the Longitudinal Employment Household Dynamics (LEHD). The variables of interest (WAC-LEHD) for this section are the total number of jobs in a) Retail Businesses- NAICS 44-45 b) Knowledge Sector - NAICS 51 (Information), NAICS 52 (Finance and Insurance), NAICS 54 (Professional, Scientific and Technical Service), NAICS 55 (Management of Companies and Enterprises), c) Service Sector - NAICS 72 (Accommodation and Food Services), NAICS 81

(Other Services).

This case study uses a difference-in-difference approach to understand the longitudinal economic impact of the light rail for five years (2008- 2013) and ten years (2008-2018). It compared the impact of light rail service on employment growth (retail, knowledge, and service sectors) within a half-mile buffer from the Clackamas Transit Center (Treatment group) with the impact of employment growth half-mile to one-mile buffer from the transit stop (Control). This approach will help us understand the impact of the new light rail service on the jobs around the Clackamas transit center by comparing it with the control group, i.e., the number of workers outside the half-mile buffer. It is assumed that these workers do not depend on transit to get to work (a distance greater than half a mile is not considered walkable). 


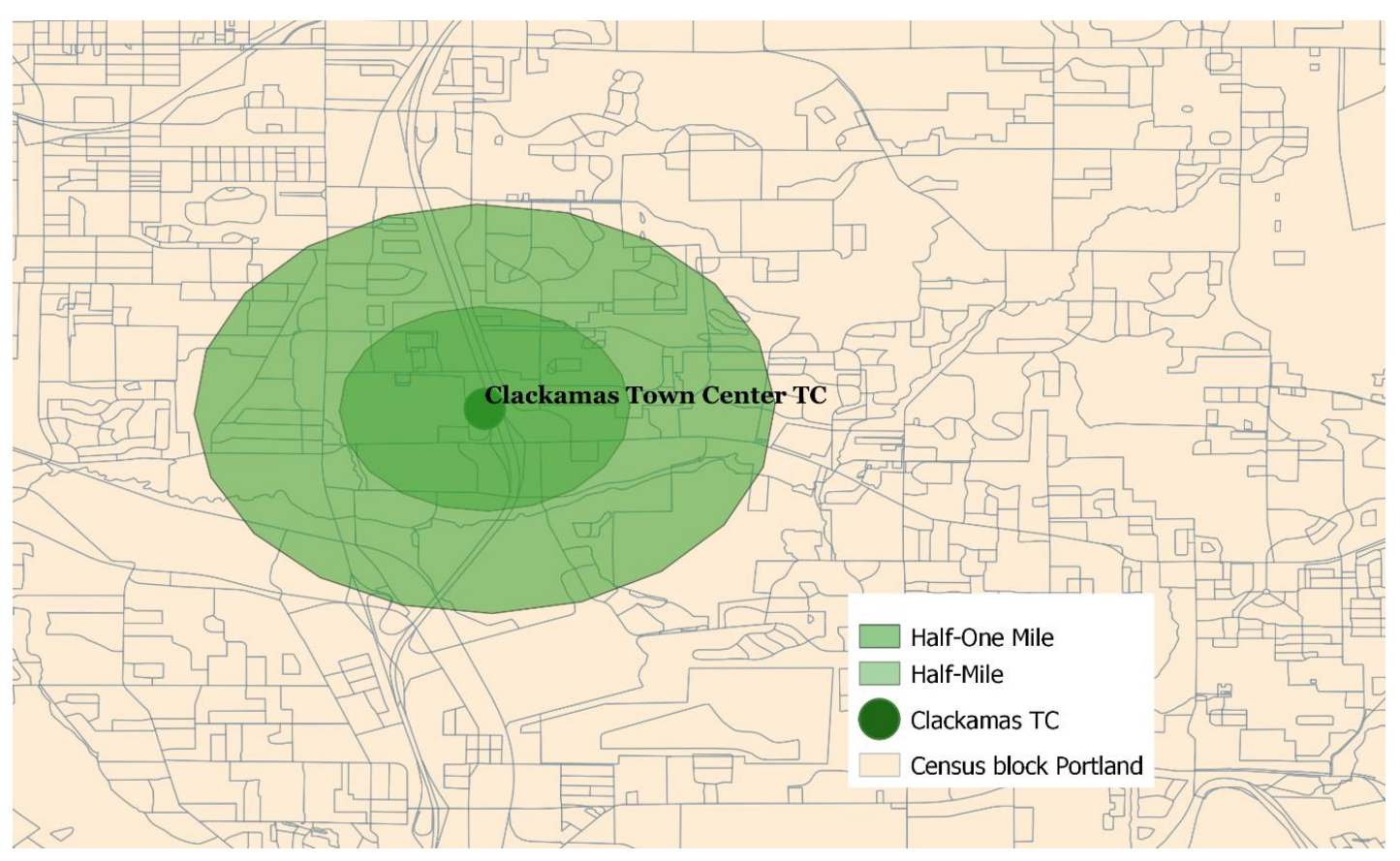

Figure 10-Study ARea Clackamas Town Center Transit Center

\subsubsection{TREATMENT AND CONTROL GROUPS}

A half-mile buffer has been calculated at a census block level around the Clackamas Town Center Transit stop for the treatment area. In addition, a half to one-mile buffer around the same transit stop has been selected for the control area based on the US Census 2008, 2013, and 2018 block shapefiles (United States Census Bureau, 2008, 2013, 2018).

Figure 10 shows the treatment and control area. The buffer distance of half a mile has been known as the standard area of impact around the transit stations (Mohammad et al., 2013) (Zhao et al., 2003). 


\subsubsection{CALCULATION OF THE STUDY AREA}

GIS tools were used to calculate the amount of land from each block that falls within the half-mile buffer treatment area and control area for the Clackamas Town Center Transit Center. The census variables for each block have been weighted by the land share by dividing the total census block area and multiplying it by the fraction of census block area that falls within the study area (total jobs/square mile). To further normalize, I have divided the aggregate of the variables (total, retail, knowledge, service sector jobs) by the total buffer area (5.91 square miles for half a mile buffer \& 8.42 square miles for half-to one-mile buffer).

TABLE 5- DIFFERENCE IN DIFFERENCE ESTIMATION OF LIGHT RAIL SERVICE ON CLACKAMAS REGIONAL CENTER BETWEEN 2008 AND 2013

\begin{tabular}{|l|l|l|l|l|l|}
\hline \multicolumn{7}{|c|}{ Differences in Difference Estimation for Five Years } \\
\hline Variables & Pre-treatment & Post-treatment & Pre-Control & Post-Control & Diff-in-Diff \\
\hline Total Jobs & 33.62 & 983.36 & 119.01 & 677.55 & 391.20 \\
\hline Retail & 15.71 & 410.97 & 54.55 & 181.01 & 268.79 \\
\hline Knowledge & 0.88 & 120.56 & 9.66 & 54.79 & 74.55 \\
\hline Services & 11.49 & 187.10 & 24.31 & 80.54 & 119.39 \\
\hline
\end{tabular}


TABLE 6-DIFFERENCE IN DIFFERENCE ESTIMATION OF LIGHT RAIL SERVICE ON CLACKAMAS REGIONAL CENTER BETWEEN 2008 AND 2018

\begin{tabular}{|l|l|l|l|l|l|}
\hline \multicolumn{6}{|c|}{ Differences in Difference Estimation for Ten Years } \\
\hline Variables & Pre-treatment & Post-treatment & Pre-Control & Post-Control & Diff-in-Diff \\
\hline Total Jobs & 33.62 & 1584.95 & 119.01 & 1141.68 & 528.66 \\
\hline Retail & 15.72 & 407.30 & 54.55 & 217.21 & 228.92 \\
\hline Knowledge & 0.88 & 121.48 & 9.66 & 62.83 & 67.44 \\
\hline Services & 11.49 & 262.44 & 24.31 & 78.88 & 216.39 \\
\hline
\end{tabular}

\subsubsection{RESULTS}

Table 5 shows that between 2008 and 2013, there has been an increase of 390 jobs half a mile from the Clackamas Transit Center compared to the half-mile to one-mile distance. In addition, Retail, Knowledge, and Service Sectors have seen an increase of 268, 74, and 119 jobs respectively within the half-mile buffer from the Clackamas Transit Center compared with the half to one-mile buffer. Table 6 shows a similar pattern for ten years between 2008-2018. Although the Retail, Knowledge, and Service sectors show an increase of $228,67,216$ jobs respectively in the half-mile buffer distance from the Clackamas Transit Center between 2008 and 2018, the number of jobs in Retail and Knowledge sectors when compared with the five years impact has declined. Thus, we can say that there was no further growth in employment in these three sectors after the first five years since the Greenline service opened in 2009. 


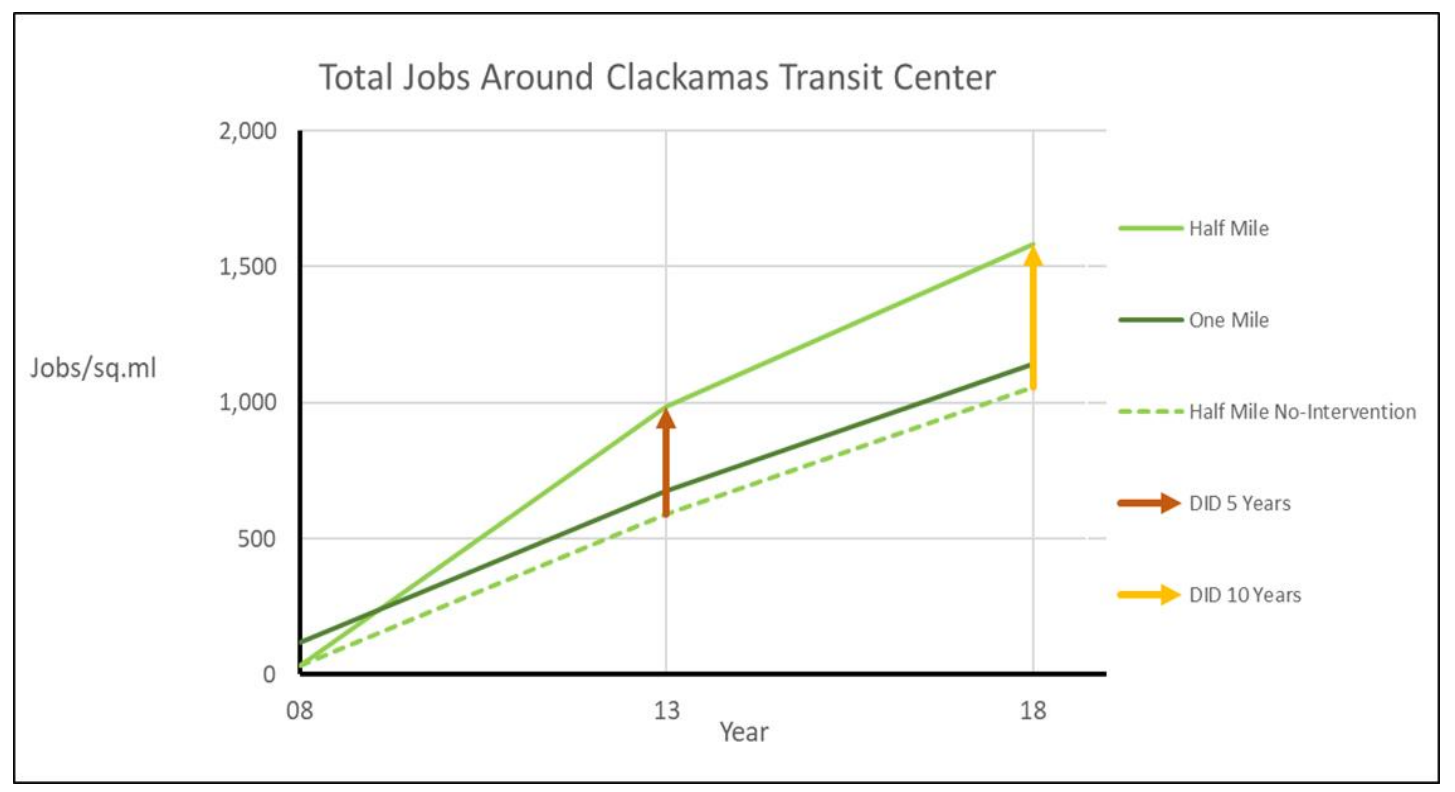

FIGURE 11- SHOWING THE IMPACT OF LIGHT RAIL SERVICE ON TOTAL JOBS AROUND THE CLACKAMAS TRANSIT CENTER

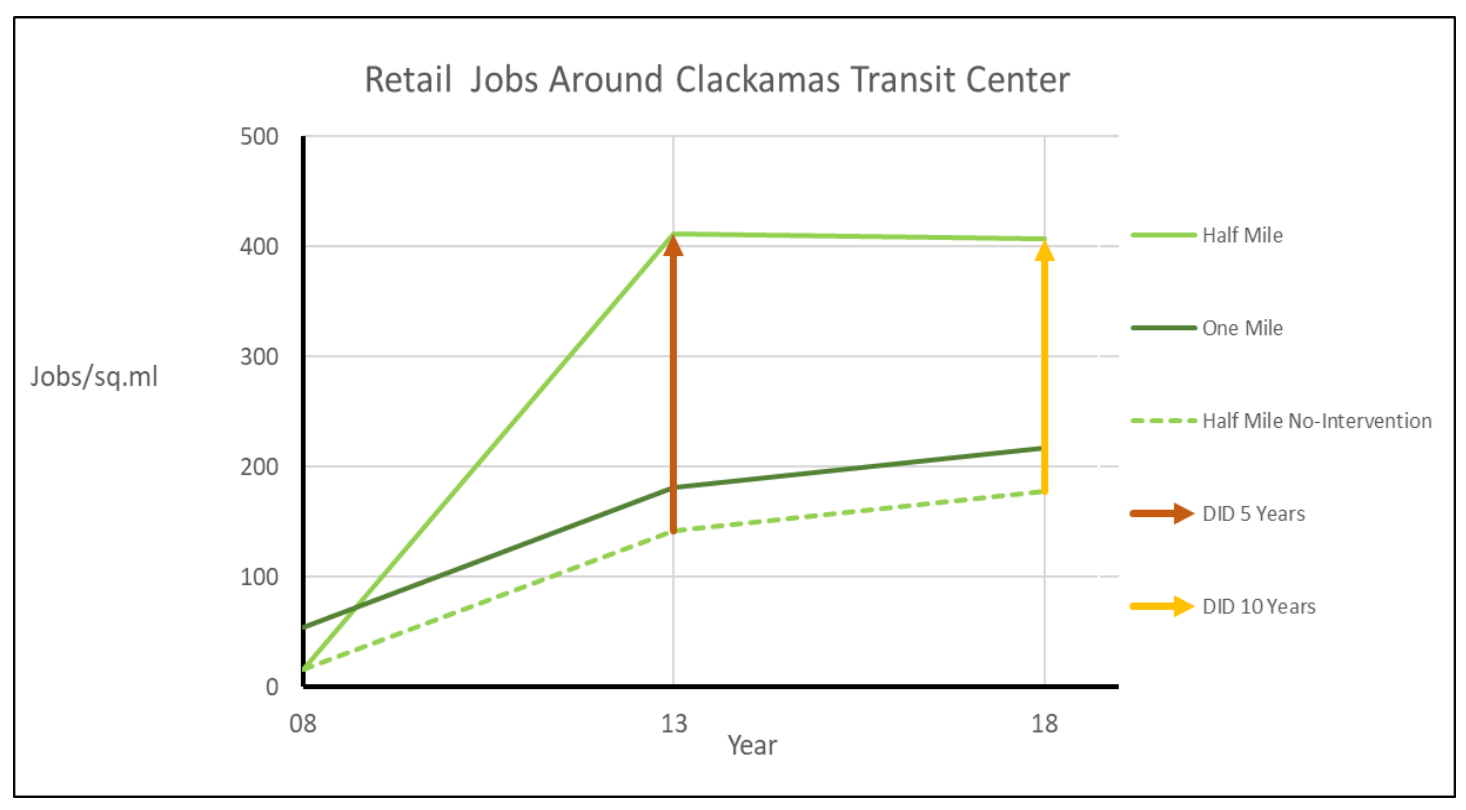

FIGURE 12-SHOWING THE IMPACT OF LIGHT RAIL SERVICE ON RETAIL JOBS AROUND THE CLACKAMAS TRANSIT CENTER 
The new LRT service impacted the retail industry employment around the Clackamas Transit Center more than the knowledge and service sector, as shown in Figures $12,13 \& 14$. The Retail industry contributed to about $68 \%$ of the total employment change, as seen in table 5 between 2008 and 2018. This result supports the perspective that the Clackamas Station area design choices are conducive to retail development.

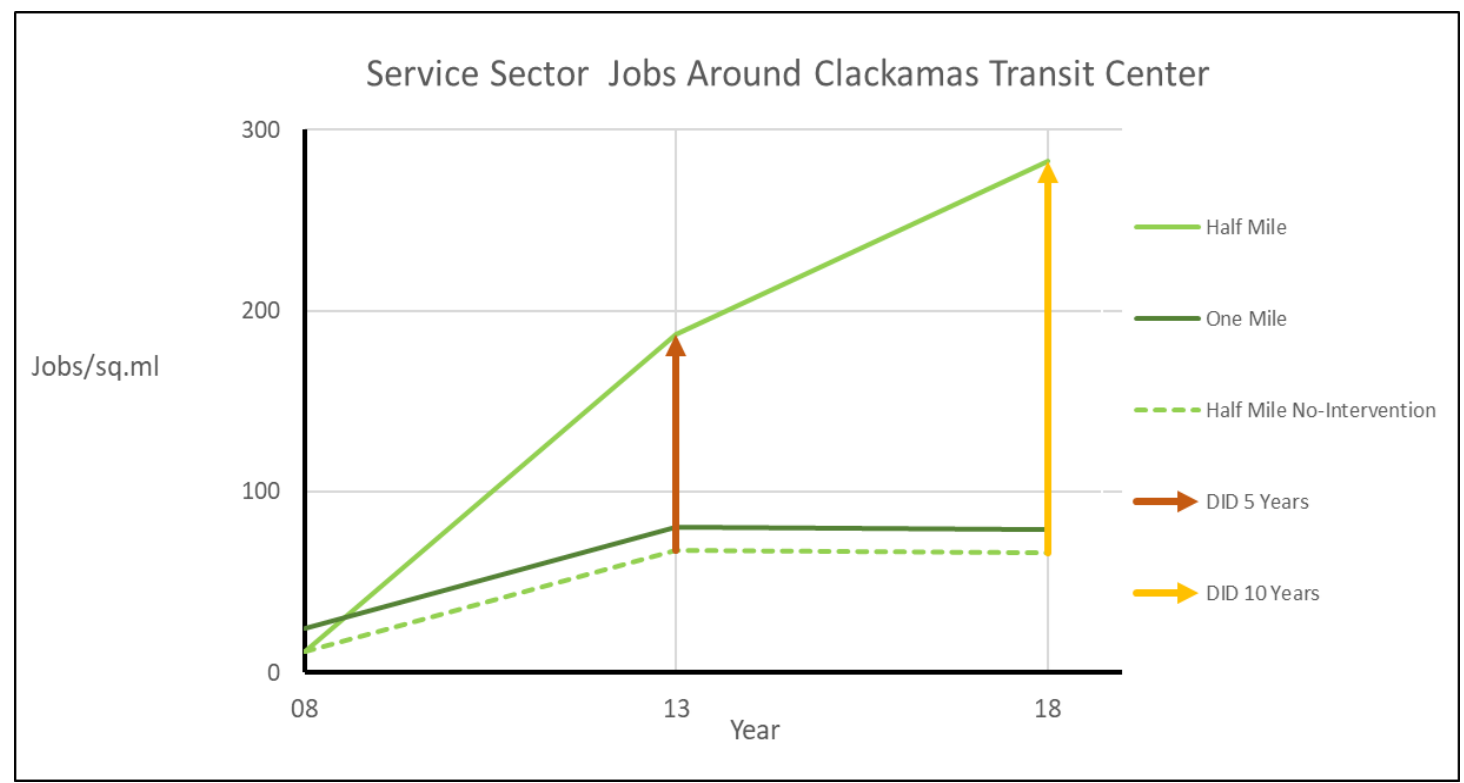

FIGURE 13- SHOWING THE IMPACT OF LIGHT RAIL SERVICE ON SERVICE SECTOR EMPLOYMENT AROUND THE ClaCKAMAS TRANSIT CENTER 


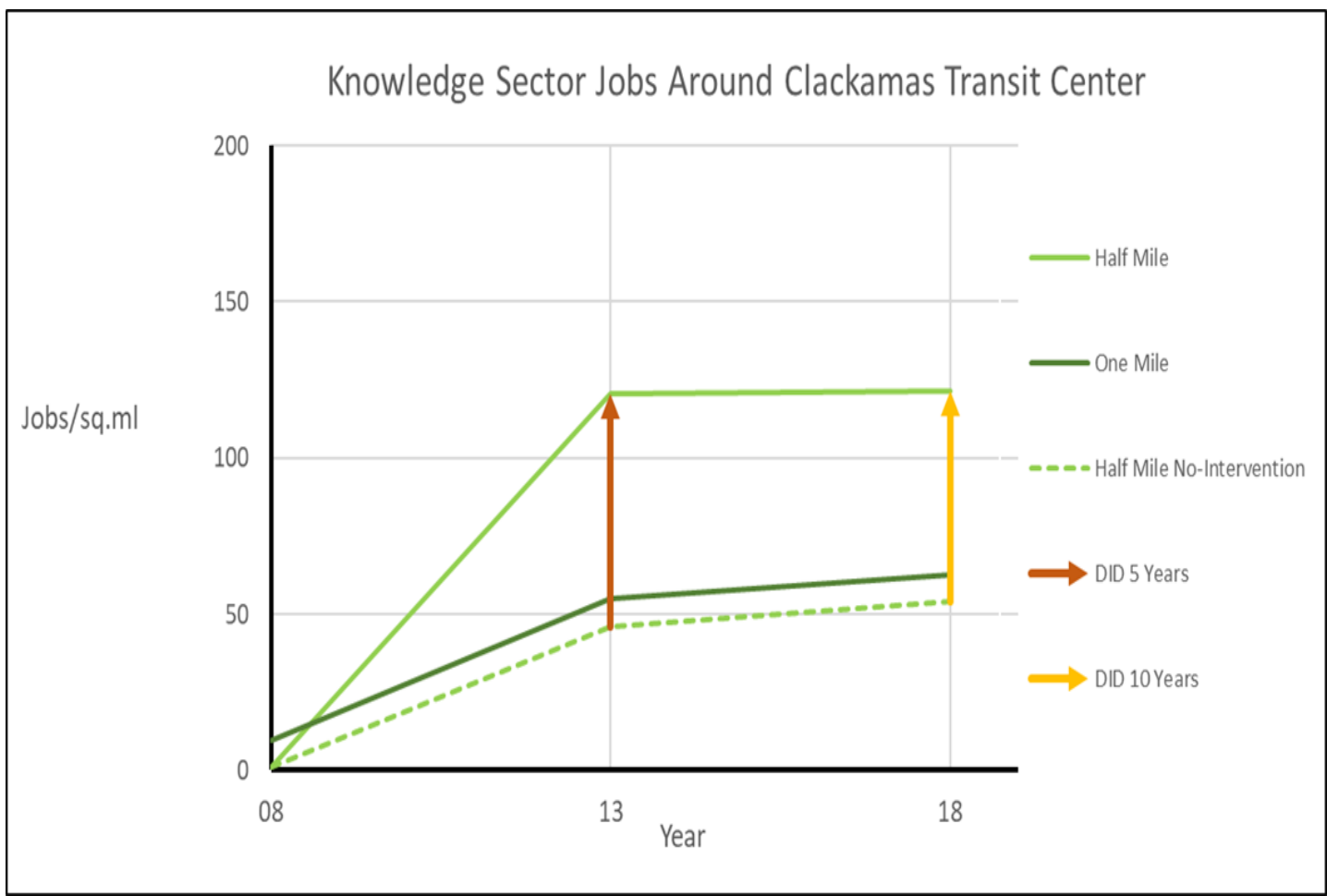

FIGURE 14-SHOWING IMPACT OF LIGHT RAIL SERVICE ON KNOWLEDGE SECTOR JOBS AROUND THE CLACKAMAS TRANSIT CENTER 


\subsection{LENTS TOWN CENTER}

SE Foster Road is a classic automobile-oriented arterial connecting outer SE Portland and the historic Lents neighborhood with downtown Portland and the Powell, Division, and Hawthorne commercial corridor districts. The corridor segments between Lents and Powell Boulevard have automobile-oriented land use but with various pockets of medium-density mixed use. Street connectivity in the residential neighborhoods that surround Foster is high. Although the land uses in Foster do not promote walkability nor have adequate pedestrian infrastructure, it could promote an excellent non-automobiledependent lifestyle. Hence, Metro should invest in a medium-density TOD project as a way to further develop the region.

As mentioned earlier, the I-205/Portland Mall Light Rail Project led to creating the Green Line, which connects two regional centers, the Gateway and the Clackamas, and a town center Lents, as identified in the 2040 Metro Growth Concept. Town centers provide an array of commercial and housing options that may help the residents to reduce trips out of the area for the basic services. One of the key elements of such town centers is a transportation system along with pedestrian and bike infrastructure and transit access.

This chapter presents a case study of the impact of LRT accessibility (Lents transit center) on employment growth in the retail, knowledge, and service sectors in the Lents Town Center, evaluating the TOD benefits in Lent. 


\subsubsection{DATA}

Like the LRT chapter, the data used here is Workplace Area Characteristic (WAC) data from the Longitudinal Employment Household Dynamics (LEHD). The variables of interest (WAC-LEHD) for this section are the total number of jobs in a) Retail BusinessesNAICS 44-45 b) Knowledge Sector - NAICS 51(Information), NAICS 52(Finance and Insurance), NAICS 54(Professional, Scientific and Technical Service), NAICS 55(Management of Companies and Enterprises) c) Service Sector- NAICS 72(Accommodation and Food Services), NAICS 81( Other Services).

This case study uses a difference-in-difference approach to understand the longitudinal economic impact of the light rail for five years (2008-2013) and ten years (2008-2018). It compared the impact of light rail service on employment growth (retail, knowledge, and service sectors) within a half-mile buffer from the Lents Transit Center (Treatment group) with the impact of employment growth half-mile to one-mile buffer from the transit stop(Control). This approach will help us understand the impact of the new light rail service on the jobs around the Lents transit center by comparing it with the control group, i.e., the number of workers outside the half-mile buffer.

\subsubsection{TREATMENT AND CONTROL GROUPS}

A half-mile buffer has been calculated at a census block level around the Lents Transit Center for the treatment area. In addition, a half to one-mile buffer around the same 
transit stop has been selected for the control area based on the US Census 2008, 2013, and 2018 block shapefiles (United States Census Bureau, 2008, 2013, 2018).

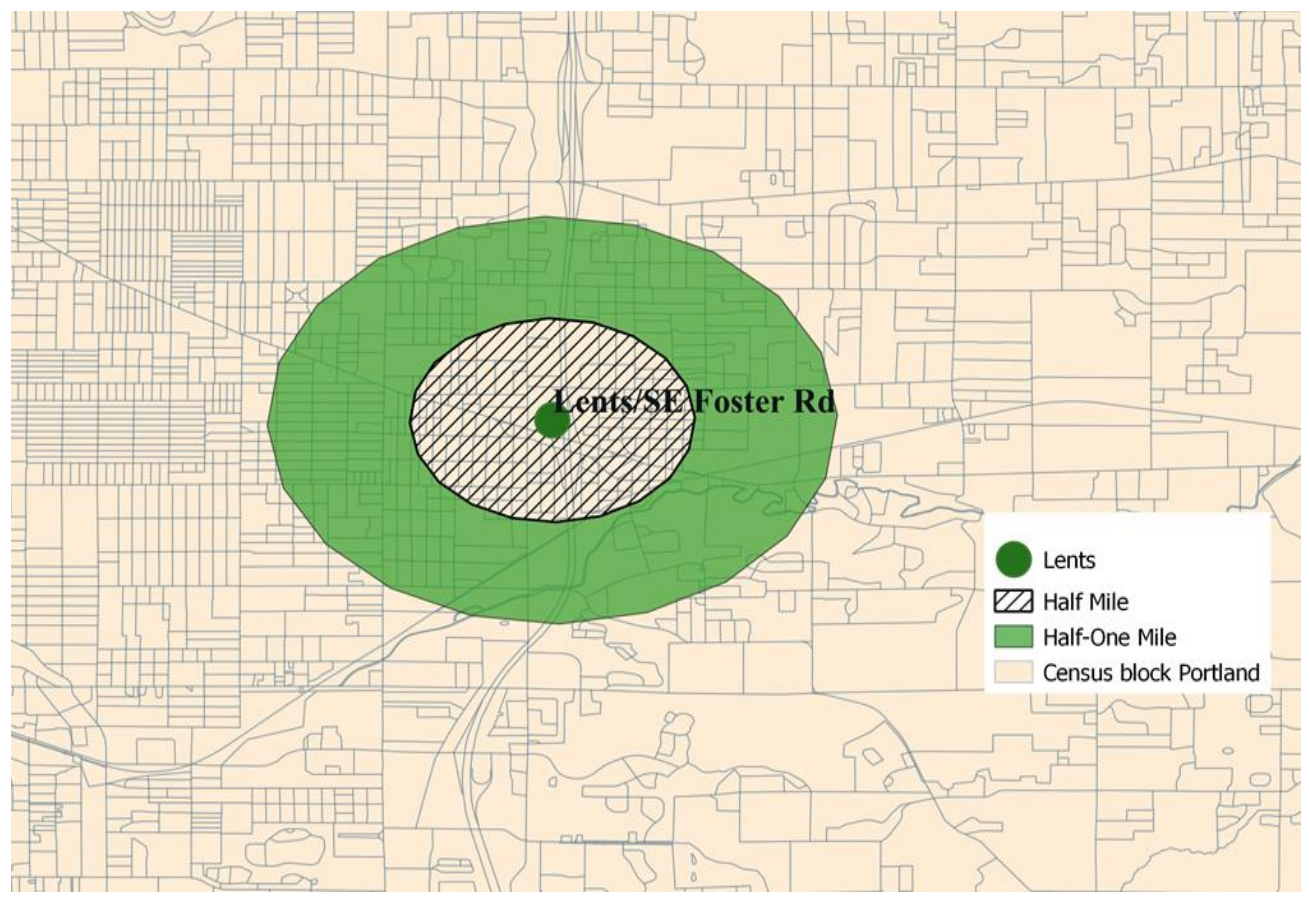

Figure 15-STUdy AREA AROUND LENTS/SE Foster Rd TRANSIT CENTER

\subsubsection{CALCULATION OF THE STUDY AREA}

Like the Clackamas Town Center Transit Center, the census variables were normalized according to the area in the treatments and control station area around the Lents Transit Center.

\subsubsection{RESULTS}

Table 7 shows that between 2008 and 2013, there has been a decline of 81 jobs with half a mile distance from the Lents Transit Center compared to the half a mile to one-mile 
distance. The Retail, Knowledge, and Service Sectors have seen a decline of 43, 9 and 4 jobs respectively within the half-mile buffer. Table 8 shows a similar pattern for ten years between 2008-2018. Although the retail shows a slight increase of 32 jobs over the years. The knowledge, and service sectors continue to show a decline of 4 and 19 jobs respectively. Figure 16, 17, 18 show the trend of employment growth in the Lents Town Center before and after opening of the Greenline.

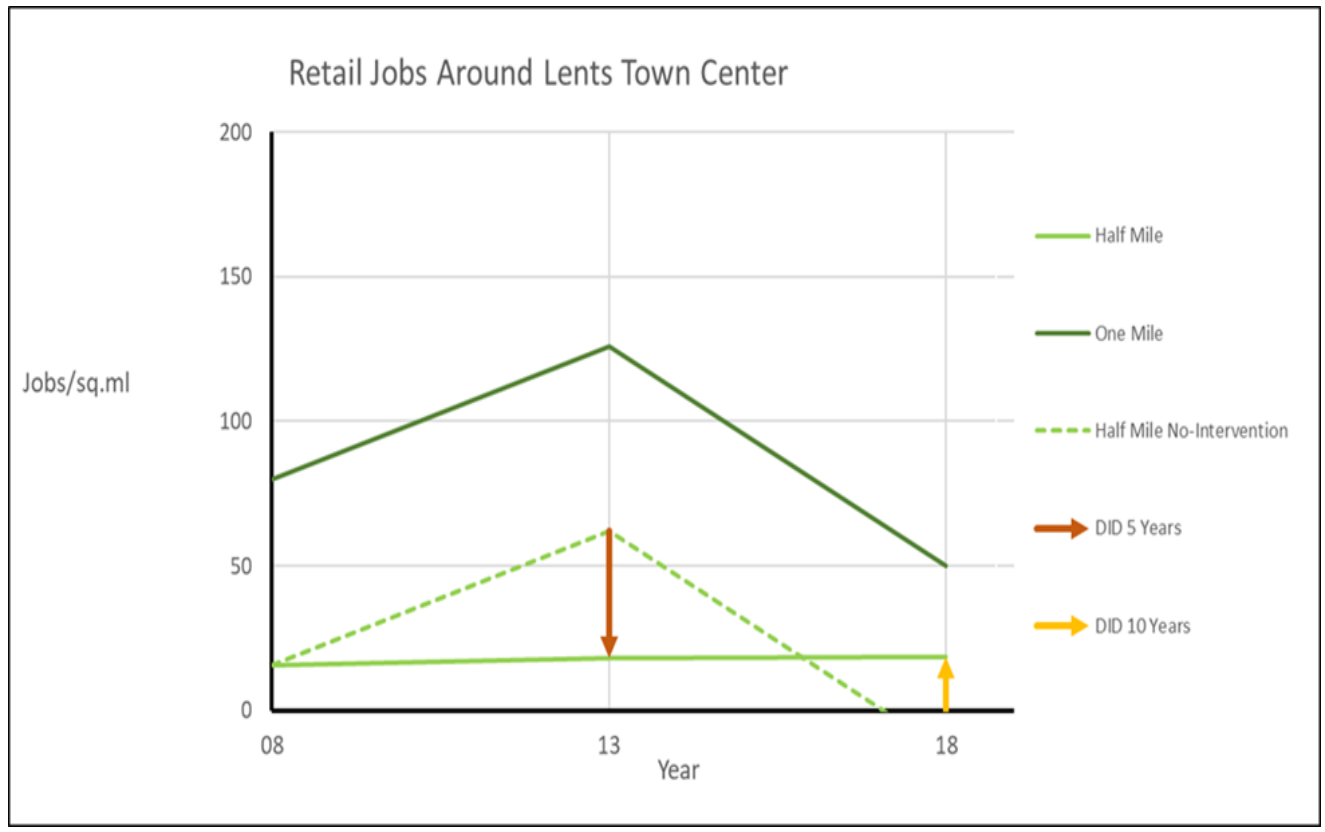

FIGURE 16-SHOWING IMPACT OF LIGHT RAIL SERVICE ON RETAIL SECTOR JOBS AROUND THE LENTS TOWN CENTER 


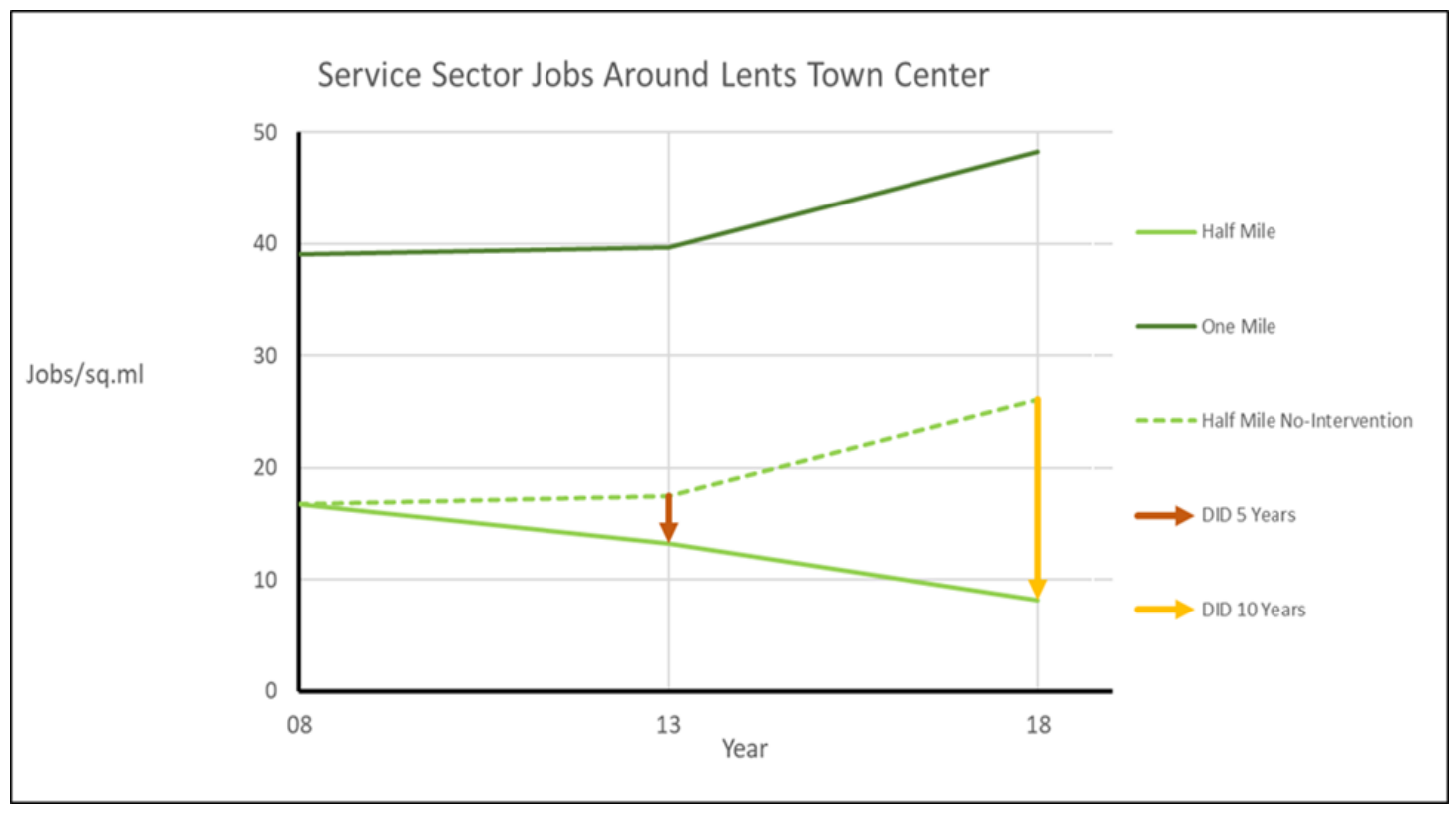

FIGURE 17-SHOWING IMPACT OF LIGHT RAIL SERVICE ON SERVICE SECTOR JOBS AROUND THE LENTS TOWN CENTER

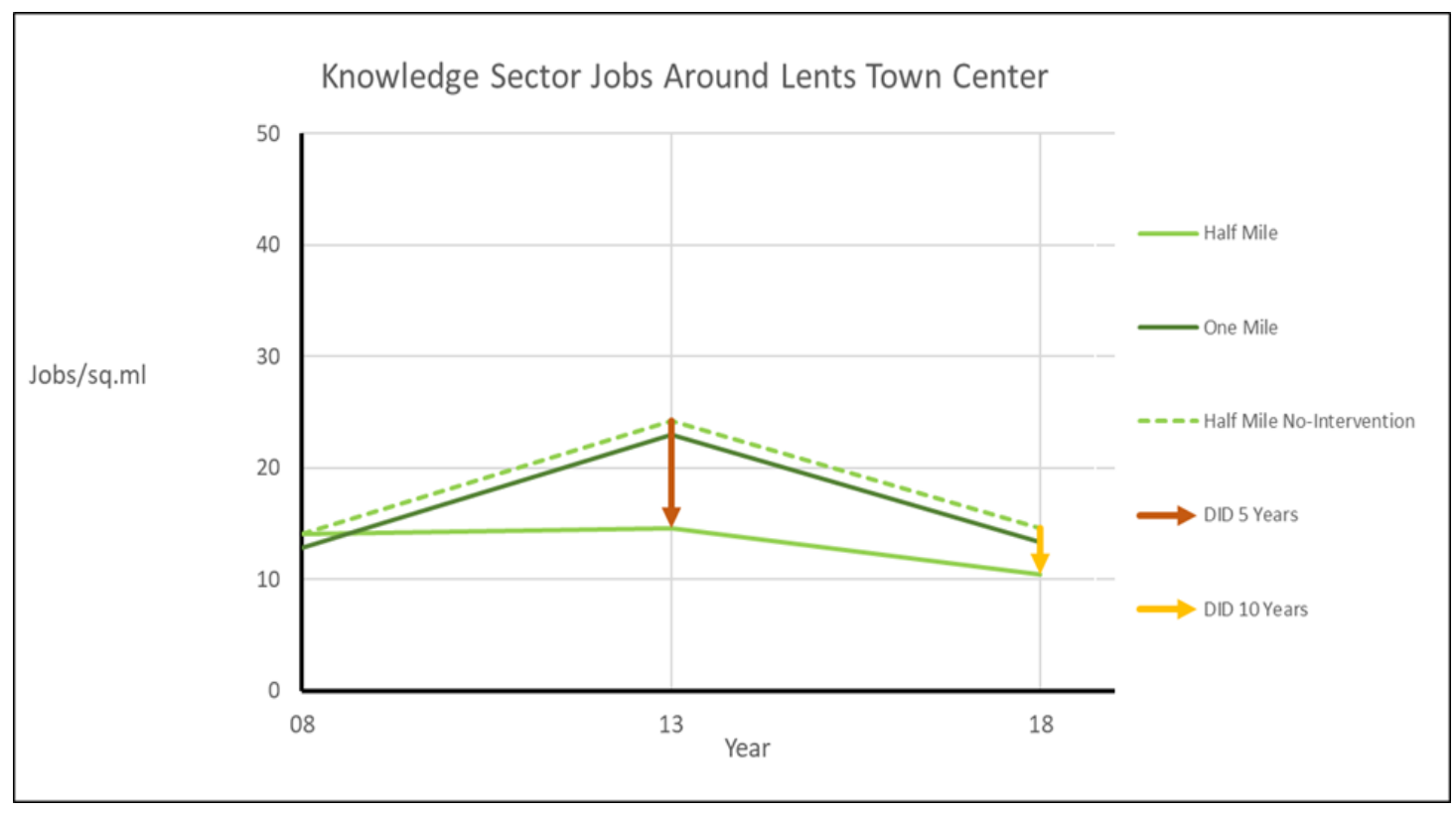

FIGURE 18-SHOWING IMPACT OF LIGHT RAIL SERVICE ON KNOWLEDGE SECTOR JOBS AROUND THE LENTS TOWN CENTER 
TABLE 7-DIFFERENCE IN DIFFERENCE ESTIMATION OF LIGHT RAIL SERVICE ON LENTS TOWN CENTER BETWEEN 2008 AND 2013

\begin{tabular}{|l|l|l|l|l|l|}
\hline \multicolumn{7}{|c|}{ Difference in Difference Estimation for 5 years } \\
\hline Variables & Pre-Treatment & Post-Treatment & Pre-Control & Post- Control & Diff_in_Diff \\
\hline Total Jobs & 105 & 122 & 203 & 301 & -81 \\
\hline Retail & 16 & 18 & 80 & 126 & -44 \\
\hline Knowledge & 14 & 15 & 13 & 23 & -10 \\
\hline Services & 17 & 13 & 39 & 40 & -4 \\
\hline
\end{tabular}

TABLE 8-DIFFERENCE IN DIFFERENCE ESTIMATION OF LIGHT RAIL SERVICE ON LENTS TOWN CENTER BETWEEN 2008 AND 2018

\begin{tabular}{|l|l|l|l|l|l|}
\hline \multicolumn{7}{|c|}{ Difference in Difference Estimation for 10 years } \\
\hline Variables & Pre-Treatment & Post-Treatment & Pre-Control & Post- Control & Diff_in_Diff \\
\hline Total Jobs & 105 & 132 & 203 & 293 & -63 \\
\hline Retail & 16 & 19 & 80 & 50 & 33 \\
\hline Knowledge & 14 & 10 & 13 & 13 & -4 \\
\hline Services & 17 & 8 & 39 & 50 & -20 \\
\hline
\end{tabular}

\subsubsection{CONCLUSIONS}

The study results suggest that there is a positive relationship between transit accessibility and employment along the selected Greenline corridor. The immediate benefits of the LRT service grew gradually over ten years for the selected corridor in 
Southeast Portland. As expected, the results for the individual station or Clackamas Transit Center show a positive change in employment after opening the Greenline in 2009, although the rate of growth has not been significantly different for the sectors of interest. It shows a lower-level impact in job growth than what was observed immediately after the line opened. Overall, there was approximately a $30 \%$ increase in the total number of jobs in Clackamas Town Center when compared with the first five years. The retail sector has shown a significant positive impact when compared to other sectors. Another key contributing factor may be an area of currently existing high employment density-the Clackamas employment hub.

The second TOD case study (on Lent Town Center) paints an entirely different picture. Transit accessibility has had no impact on employment growth around the Lents Transit Center. The results for both the five-year and ten-year phases show a decline in jobs. However, the number of retail jobs increased by 30 over ten years. Although there has been pressure for Lent's Business District Transportation Plan to reverse the economic decline in the neighborhood, the impact of LRT service in Lent seems discouraging. The business district core is centered at the intersection of Foster Road and $92^{\text {nd }}$ Ave. Its proximity to the Interstate 205 freeway and extensive traffic through the core business district contribute to a poor pedestrian environment.

Transit accessibility has made a significant change in retail jobs along the corridor of Greenline, thus lending credence to the claim that transit accessibility increases regional access to the labor market and higher visibility through locations near the new transit 
stations. Rail stations may attract riders to the neighborhood; either the residents who moved to these neighborhoods or just commuters who pass by. Overall, an increase in the consumer density will lead to an expanded retail establishment, thus increasing the number of employees. 


\section{DISCUSSIONS}

This thesis answers the following research questions:

1) What impact does the opening of a new light rail service have on employment growth in its adjacent retail, service, and knowledge industries compared with changes in business activities in neighborhoods without a new light rail service?

2) How does employment in the adjacent retail, service, and knowledge industries change over time after new light rail service is initiated?

3) How does the impact vary on the impact of light rail transit (LRT) on new businesses as distance from the stations increases?

TABLE 9-GLIMPSE OF ALL THE CASE STUDIES EXPLAINING THE IMPACT OF LRT ON EMPLOYMENT (UPWARD ARROW IMPLIES INCREASE, DOWNWARD ARROW IMPLIES DECREASE)

\begin{tabular}{|c|c|c|c|c|c|c|}
\hline Ireatment Group & Control Group & Years & Total Jobs & Retail & Knowledge & Services \\
\hline Half-mile Greenline & Half-mile Blueline & 5 & $\uparrow^{306}$ & $\uparrow^{284}$ & $\downarrow^{-10}$ & 】.63 \\
\hline Half-mile Greenline & Half-mile Blueline & 10 & $\uparrow 4147$ & $\uparrow^{1009}$ & † 209 & $\uparrow^{465}$ \\
\hline Half-mile Greenline & Half-One Greenline & 5 & $\uparrow^{375}$ & $\uparrow^{205}$ & † 34 & † 134 \\
\hline Half-mile Greenline & Half-One Greenline & 10 & $\uparrow 5188$ & 1337 & † 257 & $\uparrow 1056$ \\
\hline Half-mile Clackamas & Half-One Clackamas & 5 & $\uparrow^{391}$ & $\uparrow^{268}$ & $\uparrow^{74}$ & $\uparrow^{119}$ \\
\hline Half-mile Clackamas & Half-One Clackamas & 10 & $\uparrow^{528}$ & $\uparrow^{228}$ & $\uparrow 67$ & $\uparrow 216$ \\
\hline Half-mile Lent & Half-One Lent & 5 & \ $\quad-81$ & I -44 & $\downarrow-10$ & I 4 \\
\hline Half-mile Lent & Half-One Lent & 10 & -63 & † 33 & $\downarrow-4$ & \.20 \\
\hline
\end{tabular}


The findings tell us that the Greenline service has an impact on the employment growth for both five years (short term) and ten years (long term) in retail (include stores selling everything from groceries and office supplies, to cars and household goods), knowledge (software publisher firms in the information sector; professional, scientific services that include lawyers' offices and management consulting firms), and service sectors (hotels, restaurants, bars, and other personal services, such as dry cleaning or shoe repair). When we examine the results over ten years, we see overall job growth. Retail industry jobs increased by $255 \%$, from five years to ten years, knowledge sector jobs increased by $2190 \%$ from the first five years to ten years, service jobs showed an increase of $838 \%$ from short term to long term. Knowledge and service jobs show more of an increase because there was a decline in the number of jobs for both sectors in the first five years. It's also possible that there may be more existing retail jobs than the knowledge and service sector jobs. Overall, retail jobs contribute to about $25 \%$ increase of the total jobs, whereas knowledge and service jobs contribute to approximately 5\% and $11 \%$, respectively, in the total number of jobs across the Greenline between 2008 and 2018. The results also tell us that proximity to transit stations have facilitated job growth. Retail, Knowledge and Service jobs have increased in direct correlation to their proximity to transit stations.

The findings from the TOD analysis of Clackamas Transit Center and Lents Transit Center reveal interesting results. Overall employment has increased around Clackamas Town Center since the Greenline service has been operational. Unlike the corridor, Clackamas showed an increase in the first five years before the rate of increase flattened 
over ten years. The retail job growth declined by $14 \%$ from short term to long term, knowledge job growth declined by $9 \%$ from the short term to long term and service job growth increased $80 \%$ from short term to long term. It is possible that the impact of the first five years was due to the already existing high-employment density in Clackamas, which eventually declined. Lents Town Center analysis showed an overall decrease in employment for all the sectors of interest for both short term and long term. Retail job growth increased by $175 \%$ from short term to long term, knowledge jobs growth decreased by $400 \%$ from short term to long term, and service jobs decreased by $2000 \%$.

The first hypothesis is that the public transit facilitates the visibility of the surrounding business, increases demand, and provides access to a larger market area, resulting in increased employment in the sectors that are influenced by transit accessibility like retail, service providers and hospitality businesses. The findings explain that retail, knowledge, and service sector jobs have increased since 2009, when Greenline light rail service opened. Retail, among other sectors of interest have shown the maximum impact for both five years and ten years. In both the corridor study and Clackamas study, retail jobs have been impacted the most among all the other sectors. In the Lents study, too, the number of retail jobs tended to increase over ten years. Access to labor market is an important factor for industries without need for specialized hiring. Hence, for retail jobs, access to the labor market becomes crucial. In this case, with connections from Clackamas to Portland downtown, we can claim that the labor market access is adequate. Retail may not require a 
targeted search for employees that are usually less dependent on transportation access. In addition to the retail sector growth, we also see a positive change in employment in both knowledge and service sectors over ten years. Social networks facilitated by face-to-face communication often impact businesses like education institutions and high-tech businesses. All passenger modes increase the interpersonal accessibility and potential for building more social networks (Credit, 2018).

The second hypothesis explains that the immediate benefits of the LRT may wear off with time if the mobility benefits wear off. If the LRT system provides these mobility benefits, the accessibility benefits may be observed immediately at the opening of the LRT and the benefits may diminish over time. The results of the difference in difference analysis here suggest that employment around the Greenline corridor has continued to increase over time, in the retail, knowledge and service sectors over ten years. Thus, we can say that the LRT benefits were not just observed initially but continued to grow. The rapid increase between 2008 and 2018 as compared to 2008 and 2013 may be due to some other external factors like the Great Recession of 2009, resulting in the overall poor employment situation. Infrastructure development between 2008 and 2013 may have looked low followed by a rapid increase in ten years. However, in the Clackamas study, the long-term growth rate in all the sectors stagnated. We could assume that an already existing high employment density may have been responsible for the increase in jobs around Clackamas Transit Center in the short-term. However, stagnated growth over the long term could suggest that the LRT impact contributed to the job growth between 2009 and 2013. We may argue that in an already advanced economy like Clackamas, the accessibility levels by 
road are already high. Thus, the new infrastructure investment would affect the accessibility benefits marginally. Although, at a corridor level, the system-wide accessibility shows a positive change in employment. Hence, instead of looking at accessibility as a relative concept, it would be more beneficial to have some thresholds that can determine level of changes likely to take place. As Berechman explained, transportation investment decisions are not made in isolation(Banister \& J, 2000). The scale of investment, its location and timing of the investment are crucial factors. Transportation infrastructure as a stand-alone may not be enough to show considerable change. Change in transit accessibility enhances existing trends rather than establishing new ones. If there are existing advantageous conditions like an existing labor pool, or existing financial incentives, additional transportation accessibility may enhance these benefits.

The third hypothesis is that the proximity to the transit stops have a positive impact on job growth. Proximity is closely related to accessibility and may be key to its importance to the station area planners and businesses that would capitalize on the economic benefits of the new transit system. We anticipate that there is more development-supportive infrastructure (for example, higher density) close to the stations and this facilitates job growth. In the corridor study, there was an increase in employment with proximity to the transit stations in all sectors of interest for both the short term and long term. Similarly, in the Clackamas case study, proximity to transit stations have impacted job growth positively. Thus, we could claim that planners aiming targeted station areas for TOD 
development-supportive polices (like higher density) may be successful in looking for opportunities closer to the stations.

There are certain limitations of this study. This study has not been able to include many other relevant variables like zoning, transit ridership and overall employment growth in the Portland metropolitan region. Including these factors would have helped us better understand the magnitude of impact that LRT has had on job growth and eliminate the contribution of zoning and other underlying factors. Some of the future scopes of this study could be a qualitative analysis of the station areas and elaborating on other social contexts for regional economic development. 


\section{REFERENCES}

Adie Tomer, Elizabeth Kneebone, Robert Puentes, and A. B. (2011). Missed Opportunity: Transit and Jobs in Metropolitan America. Brookings.

Adkins, W. . (1959). Land value impacts of expressways in Dallas, Houston, and San Antonio, Texas. Highway Research Board.

Andersson, M., Klaesson, J., \& Larsson, J. P. (2016). How Local are Spatial Density Externalities? Neighbourhood Effects in Agglomeration Economies. Regional Studies, 50(6), 1082-1095. https://doi.org/10.1080/00343404.2014.968119

Banister, D., \& J, B. (2000). Transport Investment and economci Development.

Beckmann, M. (1968). Location theory. In New York.

Boschmann, E. (2011). Job access, location decision, and the working poor: A qualitative study in the Columbus, Ohio metropolitan area. Geoforum, 42(6), 671-682. https://doi.org/10.1016/j.geoforum.2011.06.005

Carteni, A. (2014). Accessibility indicators for freight transport terminals.

Cascetta, E. (2009). Transportation systems analysis: Models and Applications.

Cervero, R., Radisch, C. (1996). Travel choices in pedestrian versus automobile oriented neighborhoods. Transport Policy.

Cervero, R. (1984). Light rail transit and urban development. Journal of the American Planning Association, 50(2), 133-147. https://doi.org/10.1080/01944368408977170

Chatman, D.G.\& Noland, R. . (2011). Do public transport improvements increase agglomeration economies? Transport Reviews.

Chatman, D. G., Noland, R. B., \& Klein, N. J. (2016). Firm births, access to transit, and agglomeration in Portland, Oregon, and Dallas, Texas. Transportation Research Record, 2598, 1-10. https://doi.org/10.3141/2598-01

Credit, K. (2018). Transit-oriented economic development: The impact of light rail on new business starts in the Phoenix, AZ Region, USA. Urban Studies, 55(13), 2838 2862. https://doi.org/10.1177/0042098017724119

Credit, K. (2019). Accessibility and agglomeration: A theoretical framework for understanding the connection between transportation modes, agglomeration benefits, and types of businesses. Geography Compass, 13(4), 1-14. https://doi.org/10.1111/gec3.12425

Duranton, G., \& Turner, M. A. (2012). Urban growth and transportation. Review of Economic Studies, 79(4), 1407-1440. https://doi.org/10.1093/restud/rds010

Fischer, L. A. (2018). Financing Modern Streetcars: Assessing the Planning Impacts of 
Value Capture Implementation in Kansas City, MO. Annual Meeting of the Association of Collegiate Schools of Planning.

Frenken, K., Van Oort, F., \& Verburg, T. (2007). Related variety, unrelated variety and regional economic growth. Regional Studies, 41(5), 685-697.

https://doi.org/10.1080/00343400601120296

Gerritse, M., \& Arribas-Bel, D. (2018). Concrete agglomeration benefits: do roads improve urban connections or just attract more people? Regional Studies, 52(8), 1134-1149. https://doi.org/10.1080/00343404.2017.1369023

Giuliano, G., Gordon, P., Pan, Q., \& Park, J. Y. (2010). Accessibility and residential land values: Some tests with new measures. Urban Studies, 47(14), 3103-3130. https://doi.org/10.1177/0042098009359949

Giuliano G. (2004). Land use impacts of transportation investments: Highway and transit. The Geography of Urban Transportation.

Golub, A., Guhathakurta, S., \& Sollapuram, B. (2012). Spatial and Temporal Capitalization Effects of Light Rail in Phoenix: From Conception, Planning, and Construction to Operation. Journal of Planning Education and Research, 32(4), 415-429. https://doi.org/10.1177/0739456X12455523

Holl, A. (2004). Manufacturing location and impacts of road transport infrastructure: Empirical evidence from Spain. Regional Science and Urban Economics, 34(3), 341-363. https://doi.org/10.1016/S0166-0462(03)00059-0

Kuby, M., Barranda, A., \& Upchurch, C. (2004). Factors influencing light-rail station boardings in the United States. Transportation Research Part A: Policy and Practice, 38(3), 223-247. https://doi.org/10.1016/j.tra.2003.10.006

Landis, J., Guhathakurta, S., \& Zhang, M. (1994). UC Berkeley Earlier Faculty Research Title Capitalization of Transit Investments into Single-Family Home Prices: A Comparative Analysis of Five California Rail Transit Systems Permalink https://escholarship.org/uc/item/80f3p5n1 Publication Date. 1-38. https://escholarship.org/uc/item/80f3p5n1

Leonardi, G. (1978). Optimum facility location by accessibility maximising. Environmental Planning.

Lund, H. M., Cervero, R., \& Wilson, R. (2004). Travel characteristics of transit-oriented development in California. 5313(January), 132.

Meija, D. (2012). Transportation infrastructure impacts on firm location: the effect of a new metro line in the suburbs of Madrid. Journal of Transport Geography.

Melo, P. C., Graham, D. J., Levinson, D., \& Aarabi, S. (2017). Agglomeration, accessibility and productivity: Evidence for large metropolitan areas in the US. Urban Studies, 54(1), 179-195. https://doi.org/10.1177/0042098015624850 
Mohammad, S. I., Graham, D. J., Melo, P. C., \& Anderson, R. J. (2013). A meta-analysis of the impact of rail projects on land and property values. Transportation Research Part A: Policy and Practice, 50, 158-170. https://doi.org/10.1016/j.tra.2013.01.013

Nelson, J. . (1982). Highway noise and property values: A survey of recent evidence. Journal of Transport Economics and Policy.

Ozbay, K., Ozmen-Ertekin, D., \& Berechman, J. (2003). Empirical Analysis of Relationship between Accessibility and Economic Development. Journal of Urban Planning and Development, 129(2), 97-119. https://doi.org/10.1061/(asce)07339488(2003)129:2(97)

P, G. I. and M. (2000). Industrial clusters: Complexes, agglomeration and/or social networks? Urban Studies.

Padeiro, M. (2013). Transport infrastructure and employment growth in the Paris metropolitan margins. Journal of Transport Geography.

Porter, M. (2000). Location, competition, and economic development: Local clusters in a global economy. Economic Development Quarterly.

Saxenian, A. (1994). Location, competition, and economic development: Local clusters in a global economy.

Schuetz, J. (2015). Do rail transit stations encourage neighbourhood retail activity? Urban Studies, 52(14), 2699-2723. https://doi.org/10.1177/0042098014549128

Seo, K., Golub, A., \& Kuby, M. (2014). Combined impacts of highways and light rail transit on residential property values: A spatial hedonic price model for Phoenix, Arizona. Journal of Transport Geography, 41, 53-62. https://doi.org/10.1016/j.jtrangeo.2014.08.003

Spigel, B. (2015). Location, competition, and economic development: Local clusters in a global economy. Entrepreneurship: Theory and Practice.

Stephanedes, Y., \& Eagle, D. . (1986). Time series analysis of interactions between transportation and manufacturing and retail employment. Transporation Research Record.

Tilahun, N., \& Fan, Y. (2014). Transit and job accessibility: An empirical study of access to competitive clusters and regional growth strategies for enhancing transit accessibility. Transport Policy, 33, 17-25. https://doi.org/10.1016/j.tranpol.2014.02.002

Transit-Oriented Development Strategic Plan / Metro TOD Program. (n.d.).

Trimet. (2010). Livable Portland: Land Use and Transportation Initiatives. November, 1-124. http://bit.ly/IaCGnK 
Van Soest, D. P., Gerking, S., \& Van Oort, F. G. (2006). Spatial impacts of agglomeration externalities. Journal of Regional Science,.

Wach, M., \& Kumagai, T. . (2015). Assessing the accessibility impact of transport policy by a land-use and transport model. Environmental Urban Systems.

WC, R. S. and S. (2003). Geography, industrial organization, and agglomeration. Center for Policy Research.

Y, F. (2014). Have U.S. light rail systems been worth the investment? Freemark $Y$.

Zhao, F., Chow, L. F., Li, M. T., Ubaka, I., \& Gan, A. (2003). Forecasting transit walk accessibility: Regression model alternative to buffer method. Transportation Research Record, 1835, 34-41. https://doi.org/10.3141/1835-05 